\title{
Tourism in Greece: Strategic Analysis and Challenges
}

\author{
Dimitrios Buhalis \\ School of Management Studies for the Service Sector, University of Surrey, \\ Guildford GU2 7XH, UK
}

This paper provides a strategic analysis of the competitiveness of Greek tourism. It illustrates the importance of tourism as an economic activity and analyses the current situation and structural problems of Greece as a destination. Although Greece offers unique nature, culture and heritage, the lack of differentiation of the tourism product as well as competitive disadvantages in marketing and planning cause an over-dependence on intermediaries for the promotion and distribution of the tourism product whilst jeopardising its quality. This affects the profitability and competitiveness of both the destination and its small and medium-sized tourism enterprises. The paper proposes a grand strategy as well as numerous strategic directions, objectives and tasks aiming to demonstrate the way ahead for Greek tourism. Several major opportunities emerge through the Olympic Games in 2004 as well as the major projects currently being undertaken which will enhance the infrastructure of the country. It is argued that a consistent tourism policy based on professional developmen $t$ and implemented through a Master Plan is urgently required. Strategies and methodologies need to be identified, whilst private enterprises need to increase their cooperation locally in order to enhance the quality and competitiveness of the product.

\section{Introduction. Tourism in Greece: From Mythology to a Modern Industry}

Greece has a long tradition in tourism and hospitality mainly due to its history and ancient civilisation. Foreigners were considered sacred in ancient Greece. Xenius Zeus, the father of gods, also became the god of hospitality to protect foreigners and inspire locals to look after their visitors. A land of rich economic, religious and intellectual activity for more than three and a half millennia; geographically spread on an archipelago of more than 2500 islands; located at the south-eastern corner of Europe; on a crossroad to Africa and Asia, inevitably stimulated travel activity since the beginning of recorded history (Briassoulis, 1993: 285; Skoulas, 1985: 2; EIU, 1986: 45). In modern times, the scientific documentation of tourism in Greece commenced after the Second World War, while major tourism development started in the mid-1970s, when the unpopularity of Spanish resorts stimulated demand for alternative Mediterranean destinations. A dramatic increase of tourism flows to Greece in the late 1970s and 1980s was experienced, facilitated by plenty of natural, cultural and environmental resources, existing airport infrastructure in major islands, and lower cost of living in comparison with most of Europe (EIU, 1990: 49). Greek resorts have different product and market profiles making them capable of satisfying a great diversity of tourism demand (Buhalis, 1991; Ottaway, 1993; Boniface \& Cooper, 1994: 140; Wickers, 1993). The tourism industry grew rapidly, especially on island destinations and regions with historical monuments, as demonstrated in 
the spatial analysis of tourism distribution (Komilis, 1987; Leontidou, 1991; Papadopoulos, 1989: 297-300).

Greece is one of the most remote, peripheral, insular and poor economic regions of the EU. Its tourism requires urgent strategic management action in order to compete with alternative destinations and maximise the prosperity of the host population. Similar strategic exercises are undertaken by competing destinations around the globe, as they prepare to face the new business realities. In Spain, for example,

the evolution of demand towards a more diversified touristic product offering better value for money; the growing concern for the environment which contradicts the degradation of the surroundings; a fragmented sector structure with low level of professionalism; and a substantial growth of competition [especially new destinations which compete in its traditional market segments and enjoy comparative advantages in cost/prices] have changed the setting of Spanish tourism by constituting a serious threat to its competitiveness. However, these future trends, though worrying, can be considered as opportunities to remodel the strategy of supply of Spanish tourism. (Camison et al., 1994: 443)

Several resorts and especially Benidorm and Calvia went through a major face-lift to accommodate the new trends. Hence this paper concentrates on the factors which jeopardise the success of Greek tourism as well as on their impacts on the prosperity of the private sector and the local society and attempts to propose a strategic framework for competitiveness enhancement. Only competitive destinations will be able to maximise their benefits in the future (Buhalis, 2000a) and if Greece would like to benefit from tourism it should learn from the international experience and adapt its strategic and operational practices.

The paper is based on on-going primary and secondary research and benefits from a number of interviews with strategic players in Greek tourism. A comprehensive literature review is also incorporated in order to facilitate further research on the topic. As most destinations are comprised by an amalgam of small and medium-sized tourism enterprises (SMTEs), it is argued that the competitiveness and prosperity of destinations are closely interrelated with those of SMTEs and vice versa. This is also reinforced by Porter's (1990) analysis of 'the competitive advantage of nations' where the competitiveness of the geographical area of business operations is directly influenced by both the external business environment and the competence of local enterprises. As Camison et al. (1994: 443) state:

the conditions determining the competitiveness of a tourist service [whether accommodation, catering, a theme park, a wholesale travel agency, etc.] and the holiday experience of a tourist find meaning in a certain geographical area (the destination) defined by a multidimensional relationship among firms and industries involved, transport and communications infrastructure, complementary activities [commercial infrastructure, tradition of fairs, etc], support services [training, information, etc.], natural resources and institutional policies. 
Following the introduction and the examination of the importance of tourism in the Greek economy (why is tourism important?) the paper focuses on the strategic position of Greek tourism. A comprehensive auditing is undertaken in order to assess the current situation and to illuminate the structural problems of the industry (where are we now?). The analysis of the structural problems demonstrate several reasons which determine the strategic situation (why are we there?), while the effects on private sector profitability and the impacts of tourism on the host society are illustrated (what are the implications?). A strategic framework is provided in order to formulate a grand strategy for Greek tourism and to demonstrate future direction (where do we want to go?). Furthermore, a number of strategic directions, objectives, and tasks demonstrate how the grand strategy can be implemented, while the need for a Master Plan drawn up by the public sector and close cooperation of the private sector are prescribed in order to facilitate the implementation of the strategy (how are we going there?).

\section{Why is Tourism Important? The Contribution of Tourism to the Greek Economy}

The Greek economy is often criticised for failing to develop strong industrial sectors and to establish suitable distribution channels for exporting agriculture. Tourism is a major contributor to the balance of payments, while it is one of the few activities which would enable Greece to achieve competitive advantages through the redistribution of labour within Europe (Economist, 1993: 5-6). Thus it is a vital motivator of the Greek economy reducing the deficit of the balance of payments, boosting employment, generating income, and contributing to regional development (Zacharatos, 1989: 274; Truett \& Truett, 1987: 178).

Nobody knows the exact contribution of tourism to the Greek economy, mainly because there is inadequate research on expenditure, flows of income and national accounts. Tourism is a major export and contributor to both Gross National Product (GNP) and balance of payments. The Greek National Tourism Organisation (GNTO) suggests that the tourism contribution to the GDP is estimated at up to $7 \%$. The tourism receipts in 1998 were 5.186 millions US, covering $29.3 \%$ of the deficit in the balance of payments and $39.83 \%$ of the exports of services (www.gnto.gr, 12 October 2000). Paulopoulos (1999) estimates that in 1994 the foreign currency earned from incoming tourism was $\$ 9 \mathrm{bn}$, providing $18-20 \%$ of the GNP. Tourism income is 2.5 times more than the income generated by ind ustrial products and 1.8 times more than the total exports. However, these figures do not include pre-purchases of drachma by tourists abroad, credit card payments, payments for cruises and other earnings, which have been estimated to increase total receipts by up to $80 \%$ (EIU, 1994: 42 and 1993: 43; Papadopoulos \& Mirza, 1985: 133). Tourism is included in the Greek National Accounts as 'Invisible Receipt', and since 1989 it has only been second to the 'net EU contributions', having overtaken both 'shipping' and 'emigrant remittances' contributions, which used to dominate in the past (Epilogi, 1994: 355, Papadopoulos \& Mirza, 1985: 131; EIU, 1990: 49).

Tourism is also increasingly recognised as an instrument for regional development policies, especially for socioeconomically depressed and problematic areas (Konsolas \& Zacharatos, 1993: 57). It is instrumental in developing unfavoured regions and especially insular areas, which have little potential to develop local 
handicraft and other industries without tourism demand. Consequently, in the period 1965-1980, the tourism output multiplier in Greece was estimated to be 1.52 (Zacharatos, 1989: 281). Domestic tourism also facilitates a certain degree of redistribution of wealth between metropolitan and peripheral regions. Not only was the emigration pace from the islands diminished, especially of young people, but also a trend for rehabitation on the islands has been evident in the last decade as new job opportunities have emerged (Panagiotopoulou, 1990: 10; Loukissas, 1982: 537). Tourism also stimulates seasonal migration of professionals in several destinations, who work at the region for several months every year (Logothetis, 1990: 23). Tourism is also a major employer as it is estimated that employment in the tourism sector is 10\% (6.1\% direct employment and 3.9\% indirect) of the total employment in Greece (www.gnto.gr, 12 October 2000). Paulopoulos (1999) estimates a total of 690,000 people to be employed in tourism if we include people indirectly involved with tourism, with 35\% employed yearly, 40\% for 6-8 months and 25\% only during the peak season for $2-3$ months. About $74 \%$ of the labour is employed in accommodation establishments, $21 \%$ in travel agencies, transportation and the public sector, while a further $5 \%$ is occupied in sea transportation (Stereopoulos, 1995: 153). Job opportunities are provided mainly for young people and for women who are often self-employed within their household (Kassimati et al., 1994; Kousis, 1989: 328). However, tourism's contribution to employment is jeopardised, as increasingly the industry is using self-catering and self-serviced accommodation and catering (Zacharatos, 1989: 284).

In reality the contribution of tourism to the Greek economy is substantially greater as the official figures ignore the 'para-economy' (black or parallel economy), estimated to be as high as $28-50 \%$ of the official GDP (EIU, 1993: 25; EIU, 1990: 47). Tourism being a seasonal activity often complements other economic activities, such as agriculture and education, and therefore para-economy in tourism is even greater than other industries. Para-economy includes both international transfers of funds for tourism products offered within the country, as well as the illegal export of tourism foreign exchange which is re-exported without being processed through the Greek economic system. As a result, the real impacts of tourism in the economy are largely unknown (Zacharatos, 1988, 1989).

\section{Where Are We Now? Situation Analysis: The Greek Tourism Industry and its Competitiveness}

The contribution of Greek tourism to the national economy demonstrates the magnitude and complexity of the industry. Following a brief demand analysis, an examination of tourism supply is undertaken, whilst a strengths-weaknesses-opportunities-threats (SWOT) analysis demonstrates the competitiveness of both destination and its SMTEs. In addition the paper elaborates on a wide range of structural problems and illustrates their effects on the profitability of the private sector and on the impacts of tourism at the destination.

\section{Tourism demand for Greece}

Greece has enjoyed a continuous growth in arrivals, since the early 1950s. Despite the lack of any comprehensive tourism demand analysis undertaken by the GNTO, several research documents address the tourism-demand issue for 
Greece (Psoinos, 1994a, 1994b; GNTO, 1985a; Tourismos ke Oikonomia, 1993; NSSG, 1983, 1985, 1987, 1990, 1993; Stavrou, 1984, 1986a, 1986c). In 1950, 33,333 foreign tourists passed the borders while this figure rose to almost 11 million in 1999 , as illustrated in Table 1. Greece comes in the 17th place in the world classification of tourist destinations. There is a concentration in the summer months, as in the last ten years in 37.5\% of arrivals were in July and August, while the period May to September attracted $74 \%$ of total arrivals. This is clearly reflected on the bednights as illustrated on Table 2. Most visitors (93.2\%) originate from Europe and $70.2 \%$ from the EU, especially British, Germans, Swedish, Finnish, Dutch and Austrians. Hence, these nationalities are the dominant markets, with the British and Germans contributing almost half of all arrivals, as illustrated in Table 3. About $77.7 \%$ came by plane and $60.5 \%$ by chartered flights. Although tourism arrivals in Greece were forecasted to reach 20 million by the year 2000 (Jenner \& Smith, 1993: 161) this was not achieved as a result of increasing competition and incompetent management in both the public and private sectors.

In 1999, about 60 million bednights were recorded in all types of accommodation establishments, $75 \%$ of which were by international tourists. Similar to arrivals, the vast majority of the bednights spent in the country were by Europeans, especially British, Germans, Swedish, Finnish, Dutch and Austrians. Hence, these nationalities are the dominant markets, accounting for more than three-quarters of the bednights, with the British and Germans contributing almost half of all bednights. Domestic tourism is also a significant contributor. More than $75 \%$ of tourists arrived in Greece by air and 58\% of the total arrived on charter flights, because of the distance from the country of departure. In 1985, about $89 \%$ of tourists' arrivals to Greece were holiday-makers, while only $7 \%$ travelled for business, $2 \%$ for other reasons and 1\% were in transit. About $53 \%$ of the tourists arriving in 1985 had bought an inclusive tour package (GNTO, 1985a: 8). The inconvenience of indirect transportation schedules; large differentials in charges for groups and individual customers by accommodation establishments; lack of information about the Greek tourism product; as well as insufficient marketing by SMTEs, have enabled tour operators to act as intermediates between consumers and principals and to play a dominant role in the tourism industry. However, the development of the Internet enables prospective visitors to pre-book their packages independently and to use cheaper non-frills airlines and leisure fares of schedule airlines for their transportation.

The country has cultural attractions and heritage few other destinations can equal and therefore it can respond to the 'new era of tourism', where a greater degree of individuality and sophistication will be required by consumers. In 1998 the average length of stay in the country was 14 days, while the average expenditure per capita reached a level of $\$ 456$. Similar results emerged in recent research, although the location of the data collection produced a sample containing a higher percentage of business travellers (Psoinos, 1994a: 62).

Despite research on motivation, attitudes and satisfaction of tourists arriving in Greece being inadequate, a few typologies have emerged. Fotis (1992: 83-86) classified holiday-makers in Rhodes in four main categories: 'tranquillers' seeking quiet and relaxing holidays; 'culturers' who include a strong educational and historical element in their holidays; 'budgeters' who are predominately budget-constrained families; and young 'nightlifers' enjoying nightlife entertainment. Similarly, 
Table 1 Tourism demand and supply figures for Greece during the period 1950-1995

\begin{tabular}{|c|c|c|c|c|c|}
\hline Year & Arrivals & Bednights & $\begin{array}{c}\text { Bed } \\
\text { capacity }\end{array}$ & $\begin{array}{c}\text { Expenditure } \\
\text { (million \$) }\end{array}$ & $\begin{array}{c}\text { Expenditure } \\
\text { per capita }\end{array}$ \\
\hline 1950 & 33,333 & - & - & 4.735 & 142 \\
\hline 1951 & 40,568 & - & - & 5.933 & 146 \\
\hline 1952 & 68,184 & - & - & 9.583 & 141 \\
\hline 1953 & 94,410 & - & - & 22.721 & 241 \\
\hline 1954 & 157,618 & $1,273,105$ & - & 25.321 & 161 \\
\hline 1955 & 195,852 & $1,351,312$ & - & 29.123 & 149 \\
\hline 1956 & 218,301 & $1,594,088$ & - & 31.213 & 152 \\
\hline 1957 & 261,738 & $2,041,096$ & - & 41.374 & 166 \\
\hline 1958 & 276,534 & $2,069,722$ & - & 36.196 & 142 \\
\hline 1959 & 339,802 & $2,552,271$ & - & 41.667 & 138 \\
\hline 1960 & 399,438 & $2,963,478$ & - & 49.260 & 141 \\
\hline 1961 & 494,191 & $3,934,522$ & 57,022 & 62.469 & 142 \\
\hline 1962 & 597,924 & $4,921,803$ & 60,945 & 75.986 & 140 \\
\hline 1963 & 741,193 & $6,129,500$ & 65,604 & 95.415 & 142 \\
\hline 1964 & 757,495 & $5,102,121$ & 71,741 & 90.800 & 135 \\
\hline 1965 & 976,125 & $6,158,300$ & 78,487 & 107.575 & 127 \\
\hline 1966 & $1,131,730$ & $8,810,300$ & 85,323 & 143.458 & 144 \\
\hline 1967 & 996,473 & - & 90,362 & 126.768 & 149 \\
\hline 1968 & $1,017,621$ & - & 98,631 & 120.263 & 137 \\
\hline 1969 & $1,305,951$ & $6,212,000$ & 108,180 & 140.470 & 131 \\
\hline 1970 & $1,609,210$ & $7,683,639$ & 118,859 & 193.556 & 155 \\
\hline 1971 & $2,257,994$ & $11,224,000$ & 135,103 & 305.299 & 171 \\
\hline 1972 & $2,731,587$ & $14,687,325$ & 151,420 & 392.700 & 176 \\
\hline 1973 & $3,177,682$ & $15,698,030$ & 166,552 & 514.900 & 197 \\
\hline 1974 & $2,188,304$ & $10,214,164$ & 175,161 & 436.600 & 253 \\
\hline 1975 & $3,172,968$ & $13,574,801$ & 185,275 & 643.600 & 244 \\
\hline 1976 & $4,243,563$ & $19,202,614$ & 213,431 & 823.700 & 225 \\
\hline 1977 & $4,597,354$ & $18,714,446$ & 231,797 & 980.600 & 248 \\
\hline 1978 & $5,081,033$ & $22,259,598$ & 247,040 & 1326.300 & 293 \\
\hline 1979 & $5,798,360$ & $26,672,482$ & 265,550 & 1662.300 & 318 \\
\hline 1980 & $5,271,115$ & $27,170,344$ & 278,045 & 1733.500 & 361 \\
\hline 1981 & $5,577,109$ & $28,171,610$ & 285,860 & 1881.000 & 369 \\
\hline 1982 & $5,463,060$ & $29,954,664$ & 301,230 & 1527.200 & 303 \\
\hline 1983 & $5,258,372$ & $27,216,605$ & 317,920 & 1175.700 & 246 \\
\hline 1984 & $6,027,266$ & $32,821,789$ & 333,820 & 1312.800 & 238 \\
\hline 1985 & $7,039,428$ & $35,709,851$ & 348,170 & 1428.000 & 217 \\
\hline 1986 & $7,339,015$ & $35,450,027$ & 359,380 & 1834.200 & 261 \\
\hline 1987 & $8,053,052$ & $35,755,308$ & 375,370 & 2268.100 & 297 \\
\hline 1988 & $8,351,182$ & $36,000,000$ & 395,810 & 2396.100 & 305 \\
\hline 1989 & $8,540,962$ & $34,157,667$ & 423,790 & 1976.000 & 245 \\
\hline 1990 & $9,310,492$ & $36,289,604$ & 438,360 & 2575.000 & 290 \\
\hline 1991 & $8,271,258$ & $29,873,046$ & 459,300 & 2566.100 & 319 \\
\hline
\end{tabular}


Table 1 (cont.) Tourism demand and supply figures for Greece during the period 1950-1995

\begin{tabular}{||c|c|c|c|c|c||}
\hline Year & Arrivals & Bednights & $\begin{array}{c}\text { Bed } \\
\text { capacity }\end{array}$ & $\begin{array}{c}\text { Expenditure } \\
\text { (million \$) }\end{array}$ & $\begin{array}{c}\text { Expenditure } \\
\text { per capita }\end{array}$ \\
\hline 1992 & $9,756,012$ & $36,260,299$ & 475,800 & 3268.400 & 350 \\
\hline 1993 & $9,913,267$ & $36,747,968$ & 499,606 & 3335.200 & 354 \\
\hline 1994 & $11,301,722$ & $40,657,544$ & 486,518 & 3904.900 & 346 \\
\hline 1995 & $10,658,114$ & $38,889,975$ & 534,703 & 4294.000 & 403 \\
\hline 1996 & $9,782,061$ & $47,945,506$ & 550,692 & 3723.100 & 381 \\
\hline 1997 & $10,588,489$ & $53,364,507$ & 560,957 & 3772.200 & 356 \\
\hline 1998 & $11,363,822$ & $56,549,442$ & 577,759 & 5186.100 & 456 \\
\hline 1999 & $10,970,665$ & $60,256,902$ & 584,714 & NA & NA \\
\hline \hline
\end{tabular}

Source: Adapted from the Greek National Tourism Organisation and National Statistical Service of Greece

Wickens (1994: 819 and 2000) classified tourists arriving in Pefkochori as 'cultural heritage' type, interested in the natural beauties of Greece as well as its culture and history; 'ravers' attracted by the cheapness of the resort, particularly the cheapness and availability of alcohol as well as the sun, beach and nightlife; 'Shirley Valentines' who are women on a mono-gender holiday who hope for romance and sexual adventure with a 'Greek God' based on the Greek male stereotype which has been perpetuated by newspapers and the film Shirley Valentine; 'heliolatrous' tourists who are sun-worshippers trying indefatigably to change their colour; and finally 'Lord Byrons' who undertake an annual ritual return to the same destination and experience the real flavour of Greek hospitality and ambience. Although these typologies provide an initial demand profile, the strategic analysis and the positioning of the Greek tourism product will be impossible without further research undertaken on the characteristics, needs, motivations and behaviour of tourists.

Table 2 Nights spent by foreign tourists and Greek nationals in hotels and similar establishments by month

\begin{tabular}{||r|r|r|r|r|r|r|r||}
\hline \multirow{2}{*}{ Month } & \multicolumn{5}{|c|}{ Year } & \multicolumn{3}{|c|}{ Variation } \\
\cline { 2 - 8 } & \multicolumn{1}{|c|}{1996} & 1997 & 1998 & \multicolumn{1}{c|}{1999} & $97 / 96$ & $98 / 97$ & $99 / 98$ \\
\hline January & 867,638 & 946,798 & $1,005,719$ & $1,066,084$ & $9.12 \%$ & $6.22 \%$ & $6.00 \%$ \\
\hline February & 928,305 & 933,592 & 998,977 & $1,060,008$ & $0.57 \%$ & $7.00 \%$ & $6.11 \%$ \\
\hline March & $1,250,226$ & $1,369,751$ & $1,273,310$ & $1,448,624$ & $9.56 \%$ & $-7.04 \%$ & $13.77 \%$ \\
\hline April & $2,766,116$ & $2,822,243$ & $2,905,546$ & $2,864,693$ & $2.03 \%$ & $2.95 \%$ & $-1.41 \%$ \\
\hline May & $5,258,710$ & $5,923,093$ & $6,229,116$ & $6,617,666$ & $12.63 \%$ & $5.17 \%$ & $6.24 \%$ \\
\hline June & $6,405,495$ & $7,075,829$ & $7,530,343$ & $8,342,167$ & $10.46 \%$ & $6.42 \%$ & $10.78 \%$ \\
\hline July & $7,965,179$ & $9,003,064$ & $9,872,757$ & $10,723,835$ & $13.03 \%$ & $9.66 \%$ & $8.62 \%$ \\
\hline August & $9,551,439$ & $10,878,827$ & $11,661,790$ & $11,805,077$ & $13.90 \%$ & $7.20 \%$ & $1.23 \%$ \\
\hline September & $6,993,686$ & $7,822,329$ & $8,224,367$ & $8,756,290$ & $11.85 \%$ & $5.14 \%$ & $6.47 \%$ \\
\hline October & $4,113,665$ & $4,419,861$ & $4,640,619$ & $5,234,218$ & $7.44 \%$ & $4.99 \%$ & $12.79 \%$ \\
\hline November & $1,032,350$ & $1,113,342$ & $1,175,950$ & $1,245,219$ & $7.85 \%$ & $5.62 \%$ & $5.89 \%$ \\
\hline December & 812,697 & $1,055,778$ & $1,030,948$ & $1,093,021$ & $29.91 \%$ & $-2.35 \%$ & $6.02 \%$ \\
\hline Total & $47,945,506$ & $53,364,507$ & $56,549,442$ & $60,256,902$ & $11.30 \%$ & $5.97 \%$ & $6.56 \%$ \\
\hline \hline
\end{tabular}

Source: Greek National Tourism Organisation and National Statistical Service of Greece 


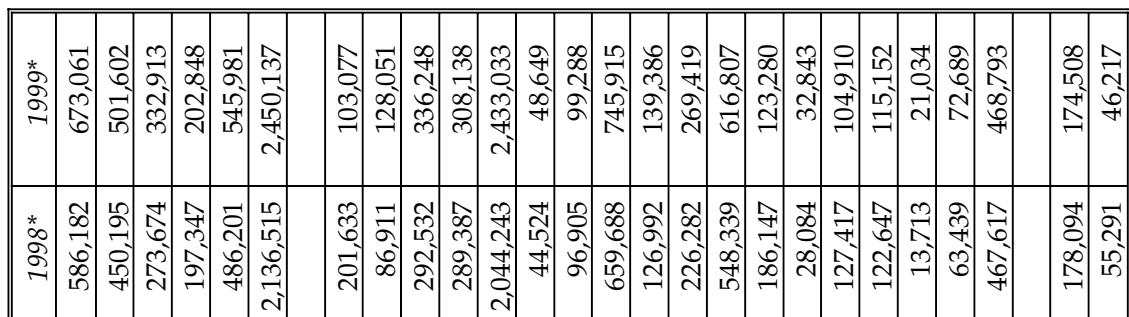

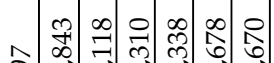

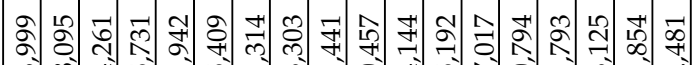

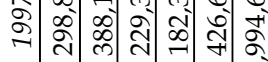

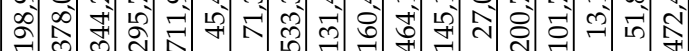

$\infty$\begin{tabular}{ll|}
$\infty$ & $\infty$ \\
$\delta$ & $\infty$ \\
\hdashline
\end{tabular}

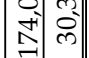

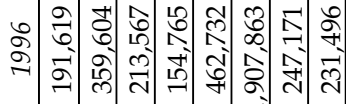

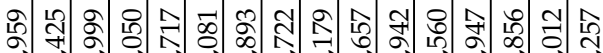

๙ิ

要

令

各

น

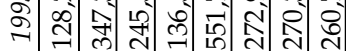

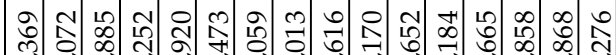

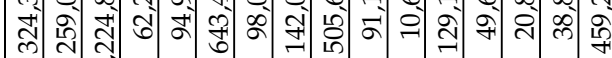

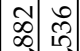

今)

\section{+1 年 \\ ने ले ले की}

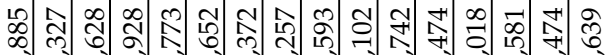

के

뉸

$\infty$

.्己

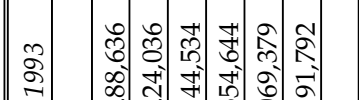

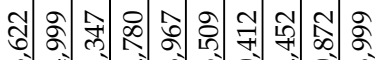

के

సิ

$\sim \quad$ ते

ले तें की

은

.

Ðี

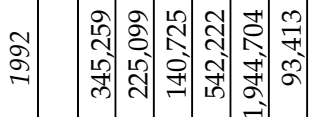

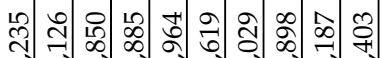

ते के ही

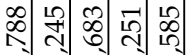

अे ते बे जी

$\pi$

.

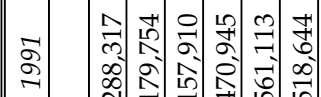

m

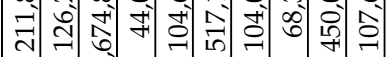

Lิ:

भे

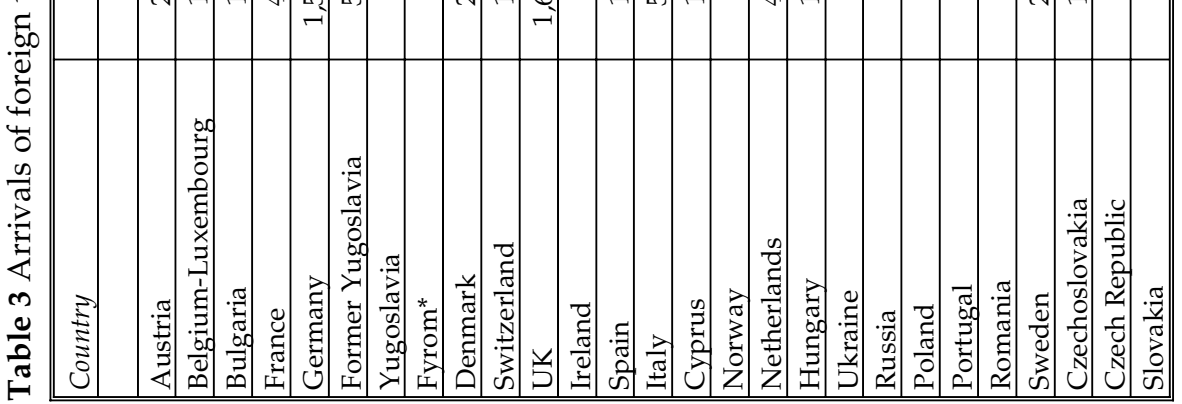




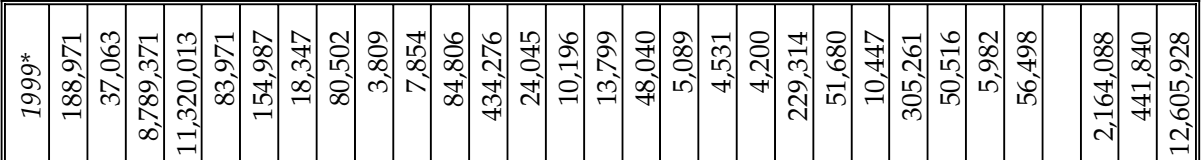

*

হे क्ञै की 성ㅇ

ㄴํำล

卷

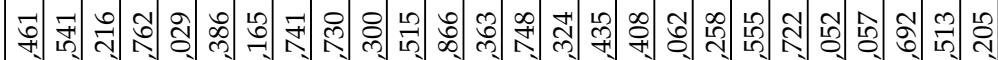

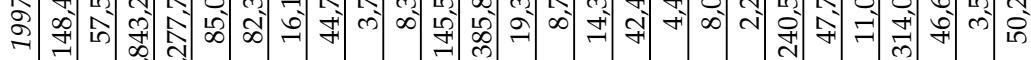

ㄴำ ซี่

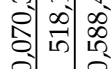
के के

의 의

ட के

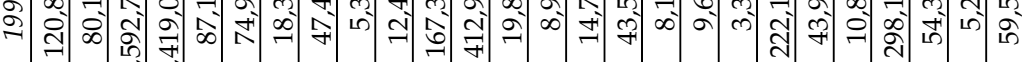

ㄴㅇㅇㄴㅇㅠ

ते 1 -

तิ ज़े

a a'

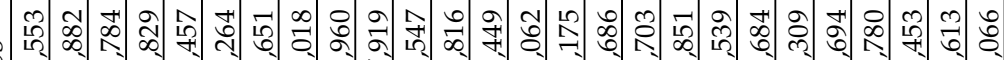

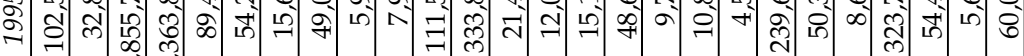

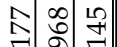

के

ब

언

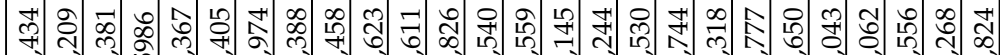

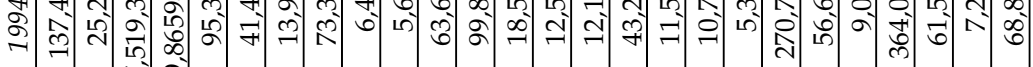

รี สี

의 $=$

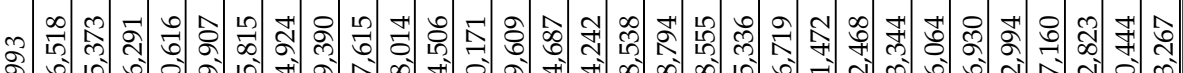

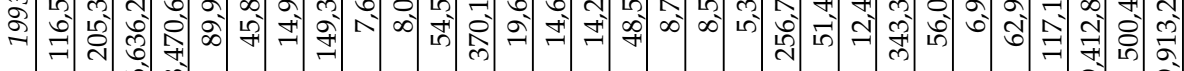

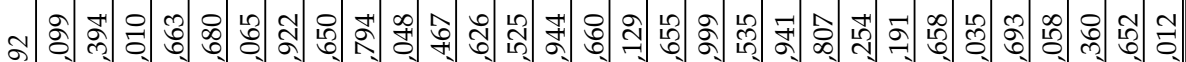

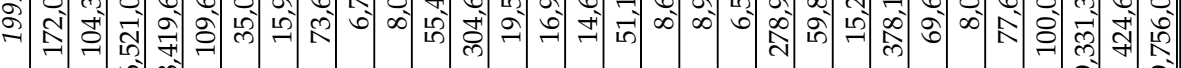

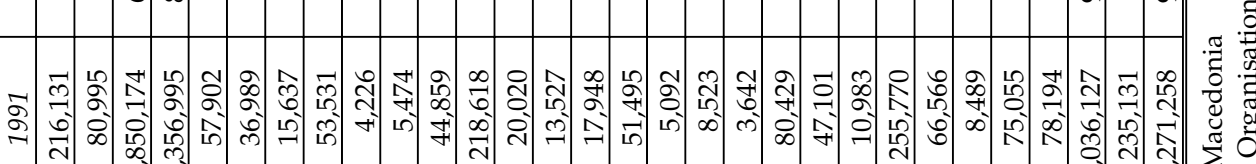

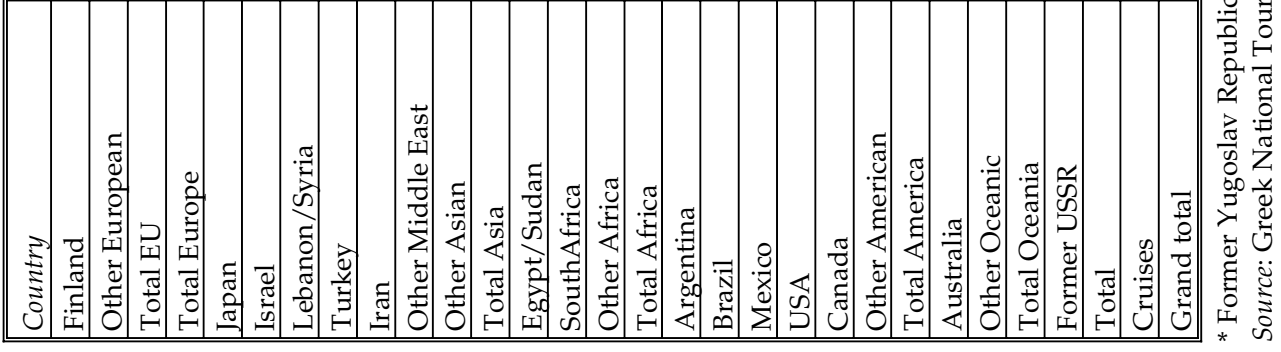




\section{Tourism supply in Greek tourism}

A modern industry has emerged since the 1950s to cater for the tourism demand. The Greek tourism product is an amalgam of natural, cultural and heritage attractions spread throughout the country, as well as a wide variety of services offered predominantly by SMTEs. Moreover, 15,000 miles of coastline; 2500 islands; an average of 300 sunny days annually; a unique fauna and flora; as well as climatic superiority with mild winters and warm summers are some of its natural attractions. The Greek civilisation of more than 3500 years also provides plentiful cultural heritage throughout the country. Some '25,000 registered and protected monuments and archaeological sites, numerous museums and about 500 characteristic traditional settlements' offer a unique blend of tourist attractions (Buckley \& Papadopoulos, 1986: 96; EIU, 1986). As far as amenities are concerned, a plethora of SMTEs provide the entire variety of services.

In January 2000, a total of 8100 official accommodation establishments with a total capacity of almost 600000 beds are provided in different categories, as demonstrated in Table 4 . Another 450,000 beds are provided by some 28,000 secondary accommodation establishments such as 'rooms to let' and self-catering apartments often referred to as 'parahoteleria'. In addition, 11,000 beds in cruise liners and 12,000 in yachts as well as 329 camping sites with 30,354 pitches and 83,000 camping spaces accommodate all types of demand (GNTO). Eurostat estimates that about 20,000 restaurants operate in Greece, while a countless number of catering and entertainment establishments are on offer. Furthermore, some 7000 travel agencies, 1500 coach rental and 4000 car rental firms are estimated to operate throughout the country (EC, 1993a).

Accessibility is facilitated through 32 airports, most of which can receive direct international charter flights. An extensive domestic scheduled flights network is provided by Olympic Airways, as well as by newly established private carriers which take advantage of the increasingly deregulated skies. The proliferation of private airlines (e.g. Aegean, Cronus, Axon, Air Greece) during the last five years and the price wars with the state-owned Olympic Airways have increased both domestic and international traffic. Moreover, a complex network of sea, road and rail transport enables passenger transportation throughout the country (Briassoulis, 1993: 291). During the last decade there has been a remarkable improvement to the quality and ability of vessels as the Greek shipping industry prepares for the lifting of cabotage in 2002, which will enable European shipping lines to operate on Greek routes. However, recent tragedies involving older Greek ferries pressurised the Ministry of Merchant Marine to take action in order to improve the safety and security of the vessels and to ensure the adequate training of crews. In addition, Piraeus port needs the development of a modern passenger terminal to provide adequate service.

Unfortunately, the Greek infrastructure is incapable of supporting the tourism superstructure growth of the last decades, and thus, telecommunications, transportation, police and health services, water supply, and sewage systems are under extreme pressure in the summer peak months to satisfy the demand density (Konsolas \& Zacharatos, 1993: 63 and EIU, 1990: 61). Nevertheless during the last decade several major projects have been initiated including the Metro and the new airport in Athens, a wide network of motorways and the gradual development of 


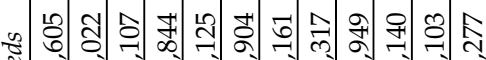

ก

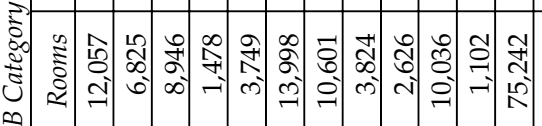

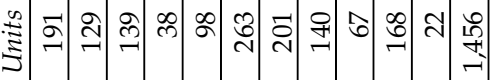

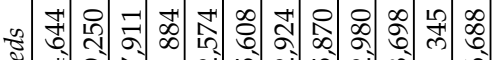

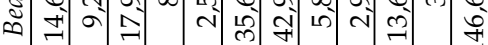

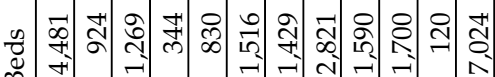

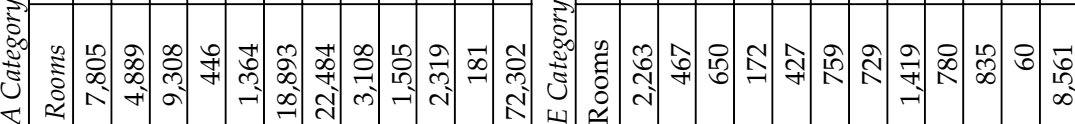

:

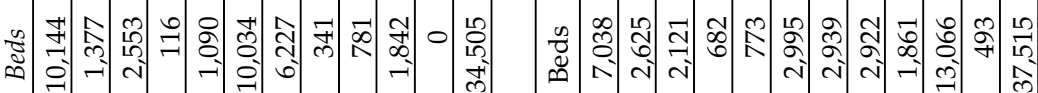

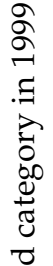

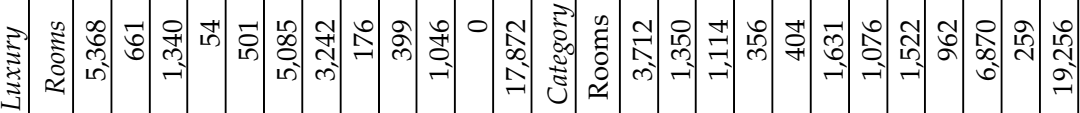

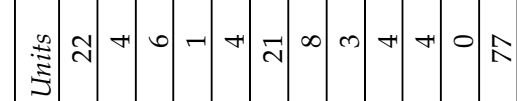

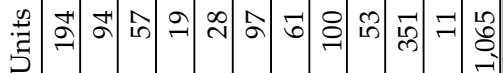

.

$\underset{Ð 0}{\infty}$

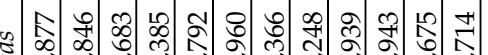

๗ँ

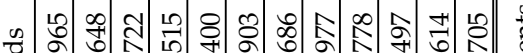

ఐ के

은

కᄑ

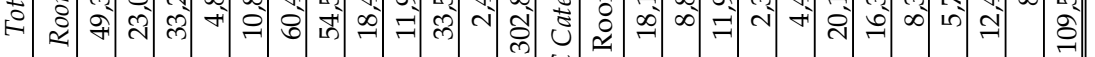

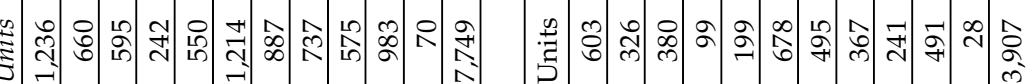


the railtrack. These developments will change the entire infrastructure of the country.

The implementation of the Greek national tourism policy is supervised by the Greek National Tourism Organisation (GNTO), and the Ministry of Tourism. The two organisations share the responsibilities for planning, implementation and promotion of Greek tourism at national and regional level, as well as coordinating the involvement of the public and private sectors in all tourism activities. Public investment in commercial facilities was utilised in the early days of Greek tourism to stimulate both tourism demand and the private sector's confidence to invest. The GNTO operates 21 regional and 25 overseas offices in 18 countries worldwide (Konsolas \& Zacharatos, 1993: 59; Leontidou, 1991; Briassoulis, 1993).

The Greek tourism product is distributed to the international market predominantly through European tour operators, which organise package holidays and include resorts in their programmes. Some 800 tour operators distribute the Greek tourism product. More than 7000 incoming travel agencies often act as tour operators' handling agencies, while providing a variety of tourism services, such as organisation of excursions, currency exchange, and accommodation bookings directly to consumers. They usually participate in negotiations between tour operators and accommodation establishments as well as cooperate with tour operators' representatives at destinations. In addition, the GNTO operates several information offices at major resorts, whilst several local authorities provide tourist information as well as distribute promotional material and make local bookings. The global GNTO network distributes information material to potential tourists, as well as undertakes all the marketing and public relations functions, both for individual and institutional customers.

\section{SWOT analysis for Greek tourism and small and medium-sized tourism enterprises}

A SWOT analysis is undertaken for the Greek tourism as well as its SMTEs in order to assess their present and projected competitiveness, based on strategic management research undertaken for the Aegean islands (Buhalis, 1991; Cooper \& Buhalis, 1992). The interrelations between SMTEs and destinations are quite apparent, illustrating that a destinations' weaknesses and threats are reflected in the SMTEs' competitiveness and vice versa. As illustrated in Table 5, the SWOT analysis concentrates on the strategic, rather than operational, strengths and weaknesses of SMTEs.

As far as strengths of the Greek tourism and SMTEs are concerned, their flexibility and ability to tailor products to consumers' needs are of great importance to their existence. SMTEs can identify profitable niches in the market, establish their requirements and attempt to satisfy specialised needs. Direct control by entrepreneurs permits quick and efficient managerial reaction to external challenges. Fewer hierarchical levels facilitate closer and more effective control over the service delivery process, enabling personal services to customers. In addition, archaeological heritage, natural and cultural resources, as well as the local character, are also significant assets. As a result, tourists benefit from local resources which are ideally situated to offer special-interest holidays. SMTEs also capitalise on personal relationships with consumers, suppliers, labour and 
Table 5 Greek tourism and SMTEs' SWOT analysis

\begin{tabular}{|c|c|}
\hline $\begin{array}{l}\text { Strengths } \\
\text { - Flexibility } \\
\text { - Tailor-made product delivery } \\
\text { - Entrepreneurial activity } \\
\text { - Family involvement } \\
\text { - Natural and cultural resources } \\
\text { - Strong local character } \\
\text { - Personalised relationships } \\
\text { - Labour loyalty and low turnover }\end{array}$ & $\begin{array}{l}\text { Weaknesses } \\
\text { - Management } \\
\text { - Marketing } \\
\text { - Information technologies illiteracy } \\
\text { - Dependence upon tour operators } \\
\text { - Supporting markets } \\
\text { - Lack of economies of scale } \\
\text { - Human resources management } \\
\text { - Education and training } \\
\text { - Transportation and accessibility } \\
\text { - Financial management and resources } \\
\text { - Seasonality } \\
\text { - Lack of standardisation } \\
\text { - Lack of quality assurances }\end{array}$ \\
\hline $\begin{array}{l}\text { Opportunities } \\
\text { - European Union support } \\
\text { - European redistribution of labour } \\
\text { - Increase in tourism demand size } \\
\text { - Trends in tourism demand } \\
\text { - Low cost of living in periphery } \\
\text { - Information technology } \\
\text { - Infrastructure development } \\
\text { - Transportation } \\
\text { - Olympic Games }\end{array}$ & $\begin{array}{l}\text { Threats } \\
\text { - Environmental degradation } \\
\text { - Concentration and globalisation } \\
\text { - Oversupply } \\
\text { - Lack of visibility in CRSs } \\
\text { - Infrastructure } \\
\text { - Wars/terrorism } \\
\text { - Political intervention }\end{array}$ \\
\hline
\end{tabular}

Source: Adapted from Buhalis 1991: 60c and Cooper and Buhalis 1992: 108

the entire tourism industry in general. Their size enables the provision of a personal finish to all products provided, while it is not unusual for customers to become friends, and to be treated accordingly. Similarly, strong relations with employees support labour loyalty and low turnover. The proprietor's family is normally directly involved with every aspect of the business, reacting efficiently and promptly to any problem arising. Their involvement in running the enterprise provides considerable benefits, especially in having a very flexible, multi-skilled and dedicated workforce which tolerates unsociable working schedules. Family members feel committed to the long-term prosperity of the enterprise and often do not distinguish between their professional and family life. Thus, a better matching between tourism demand and SMTEs' supply is achieved.

A close-up of the weaknesses of Greek tourism and SMTEs is critical for understanding the ability of the industry to compete in the global tourism arena. Although entrepreneurs are normally an asset, it seems that a number of manage- 
rial problems often arise. Lack of strategic and operational management know-how generates inconsistency in the creation and delivery of tourism products. This has direct implications for consumers' satisfaction and the projected image of the industry. There is often a complete lack of strategic vision and enterprises are often treated as an extension of proprietors' domestic environment. Entrepreneurs recruit family members and relatives as personnel and suppliers, even though more appropriate / qualified alternatives can be found in the marketplace. Therefore, the management of SMTEs clearly projects the proprietor's family life-style and decision-making processes onto an enterprise. Marketing is another significant weakness for most entrepreneurs and Greek resorts, as they are often completely unaware of the techniques available and thus follow a product-oriented rather than a consumer-orientated approach. Consequently, uncoordinated, isolated, trouble-shooting marketing activities are occasionally undertaken, rather than a consistent and well-planned marketing campaign. Lack of marketing research debilitates knowledge of consumers' needs and makes it difficult to identify methods for improving services in order to meet consumers' expectations. Inability to finance and execute advertising campaigns and other promotional techniques reduces their visibility in their markets. These weaknesses, in combination with the fact that many entrepreneurs are unfamiliar with information technology (IT), add to the problems of SMTEs in promoting themselves effectively. Consequently, both Greek SMTEs and destinations suffer from over-dependence on the tourism distribution channels to promote and distribute their product. In particular, intermediaries and especially tour operators, have enormous power within the channel and are capable of determining the Greek tourism product, marketing, distribution and pricing mixes (Buhalis, 1995). Hence, the marketing campaign and the visibility of Greek tourism to its main target markets are often determined by the coverage, space, photographs and description in tour operators' brochures. European tour operators also control accessibility to Mediterranean or long-haul destinations, as they own most charter airlines which provide direct and inexpensive flights to these destinations.

As most resorts are located in peripheral areas, there is usually little economic development in the supplying sectors. Therefore, remote destinations have to import essential raw and construction materials from elsewhere, while SMTEs often face transportation, delivery and purchasing problems and excessive transportation costs. Moreover, lack of economies of scale in purchasing raw material, low bargaining power, and lack of advanced facilities are additional operational disadvantages. This essentially means that SMTEs have to pay higher prices for products than their larger counterparts. Lack of specialised personnel and inadequate training procedures mean that human resources management is a major weakness of Greek tourism. In most SMTEs, personnel have to cover a wide range of positions, a loose job description is usually provided and multi-skilled personnel are required. The labour turnover, due to the seasonality of the tourism industry, reduces the availability of qualified and experienced personnel and makes tourism product delivery not only variable, but also unprofessional. The small size of operation provides little opportunity for the division of tasks, professional employees and proper training. Since no quality standards are introduced, service delivery varies according to the occu- 
pancy, service provider and timing. Transportation and accessibility to remote destinations may also be a weakness, as most enterprises are located in peripheral and often inaccessible regions. SMTEs tend to feel frustrated because they are unable to attract consumers, simply because they cannot provide convenient, reliable and affordable transportation. The formulation of charter air carriers by destination areas, such as Turkey and Spain, as well as the emerging deregulation policies in the European Union, may diminish this problem in the near future. Moreover, SMTEs face significant financial constraints as on the one hand they are required to invest in fixed assets at the beginning of their operations, and on the other hand, there is a discrimination against them by financial institutions, since they normally have very few assets. Consequently, they are forced to accept unfavourable financial deals. Finally, the Greek tourism industry and SMTEs suffer from seasonality problems and have to produce adequate income within a limited period every year. Lack of diversified investment in other economic activities forces proprietors to work intensively in the peak months and rest in the off-peak months, while their pay-back period is inevitably unfavourable. As the tourism industry becomes more professional, embraces quality management and responds to an increasingly discerning customer, SMTEs' typical lack of business expertise and minimal standardisation may become an increasing liability especially for some target markets (Cooper \& Buhalis, 1992: 102).

Recent developments in the external environment present numerous opportunities for the Greek tourism industry and SMTEs. Firstly, the European Union takes several actions to support small and medium-sized enterprises (EC, 1993b: 72), while it supports infrastructure development of peripheral regions and contributes significantly to the prosperity of SMTEs. The country is going through a major transformation as a result of several public projects supported by the European Commission, including the Attico Metro, the new Athens Airport, the development of the peripheral motorway Elefsina-Spata and the peripheral motorway of Immitos. The unification of the heritage sites and the pedestrianisation of the Athens city centre aims to develop an open archaeological park and deal with the traffic and pollution problems. The Olympic Games in 2004 provide a unique challenge and opportunity for the city and the country to rebrand and redevelop itself and demonstrate its unparalleled heritage and cultural resources. The Games also provide the resources and funding as well as a 'deadline' for several infrastructural projects that were already scheduled but perhaps delayed. In addition, several projects are anticipated to improve the superstructure of the industry through both renovation of existing properties and through the development of new hotels and other facilities. It is anticipated that the regeneration of the city and the country in general will provide major opportunities for the attractiveness and competitiveness of the tourism industry (Buhalis, 2000b; Papanikos, 1999; Romanos, 1998).

It is anticipated that there will be a gradual redistribution of European labour, providing support for each region to specialise in the production of goods and services where it can achieve competitive advantages. Traditionally, remote and insular destinations, where most Greek resorts and SMTEs are based, achieve a competitive advantage in tourism, and therefore greater support is anticipated. Greek tourism benefits from the continuous growth of 
global tourism demand, as more people require holiday services, while SMTEs are expected to increase their share as they tend to satisfy the emerging specialised and sophisticated demand better than larger organisations. Information and telecommunication technologies can provide strategic tools for tourism destinations and SMTEs enabling them to manage their product more efficiently, disseminate information and establish a distribution mechanism through destination management systems (Buhalis, 1994). New technologies also offer opportunities for developing innovative tourism products, such as teleworking for tourists who would like to spend time working during their stay at the destination. Finally, Greek tourism tends to achieve a cost advantage, since it employs unpaid family members and operates in inexpensive peripheral regions which often have a lower cost of living in comparison with metropolitan areas.

In terms of external threats, environmental degradation through inappropriate waste management and excessive usage of natural resources can be observed. Lack of know-how and funds effectively increases environmental problems. Consequently, several resorts suffer severe damage while entrepreneurs and local authorities feel powerless to take remedial measures. Moreover, oversupply of tourism service providers and lack of well-defined carrying capacity limits in several destinations have placed numerous Greek resorts and SMTEs in a disadvantaged position as they cannot achieve sufficient income. Similarly, the concentration of power in fewer tourism industry enterprises through emerging globalisation also threatens the ability of Greek SMTEs to survive, as international vertically integrated tourism organisations acquire control over local enterprises. The dependence upon channel partners for the promotion and distribution of Greek tourism is exaggerated by the relatively low presence of Greek suppliers in the major CRSs (Computer Reservation Systems) which is caused by the seasonality and scale of the tourism production on the one hand and the tariffs of these systems on the other. The issue of infrastructure is closely related to the oversupply which attracts higher demand than planned. Destinations often have limited infrastructure provisions which fail to follow the pace of development, generating pressure on the existing inadequate facilities. Finally, the tourism industry suffers from its geographical proximity to the Balkans and the Middle East and as a consequence is often associated by consumers with wars and terrorism activities. Greek tourism and SMTEs have limited means of dealing with unfavourable situations and thus are more vulnerable to their impacts. Political intervention, perhaps through the public sector decisions and the legislator framework often damages the prosperity of SMTEs. As SMTEs have little lobbying power they have limited influence over political decisions which determine their welfare.

The SWOT analysis demonstrates quite clearly that the Greek tourism industry faces a wide range of problems and threats which will jeopardise its ability to provide suitable tourism products in the future as well as its ability to make a contribution to the national welfare. However, several opportunities and challenges emerge and they need to be addressed in order to strengthen the competitiveness of the industry. Further analysis is therefore required in order to assess the factors which generate these problems and also to identify ways to respond to the challenges they present. 


\section{Why Are We There and What Are the Implications? Structural Problems and Challenges}

Despite its popularity and growth over the last 40 years, the Greek tourism industry has reached a stage where both its potential and competitiveness have become questionable.

The seemingly unstoppable growth of this market contributed to a degree of complacency which has led to Greece repeating some of the errors made in Spain. Rapid price increases mean the country is no longer perceived by mass market clients as cheap in relation to comparable destinations in the Mediterranean, but much of the country's tourism infrastructure, hastily built in response to demand for cheap accommodation, does not meet the needs of a market less sensitive to price and more concerned with quality and value for money. (EIU, 1990: 45)

Richter-Papaconstantinou (1992: 27) explains that tourism development in Rhodes 'takes place without any Master Plan of the area; respect of the landscape and environment; analysis whether there is demand and what the demand is after; regard to what is happening in similar situations'. At the micro level, the European travel trade and intermediaries warn that the Greek tourism product is no longer competitive (Conway, 1996: 41; Touloupas, 1996; Douvitsas, 1994), whilst Chitiris (1991: 148-150) outlines a range of managerial problems and mistakes in Greek resort hotels, which diminish the quality of the tourism services. Hence, unless the Greek tourism ind ustry addresses a number of critical issues immediately, its future might be seriously jeopardised, resulting in a potential catastrophe of the national economy. The major structural problems and challenges for the Greek tourism product can be summarised in Table 6.

As a result, Greece fails to attract the desired 'high-quality, high-expenditure' tourists, as it is increasingly unable to satisfy their requirements (Conway, 1996: 41). The deterioration of the tourism product and image leads to a lower willingness-to-pay by consumers, which consequently leads to a further drop in quality, as the industry attempts to attract customers with lower prices. This is a vicious spiral which has been destroying the essence of developing tourism in several Mediterranean destinations. The concentration of bargaining power in European distribution intermediaries and tour operators in particular, in combination with the inability of the Greek tourism industry to promote itself and establish effective distribution mechanisms, inevitably minimises the profit margins of SMTEs and their ability to yield decent returns on their investment. As a result, tourists' expenditure per capita in Greece gradually deteriorates, while their volume increases (SETE, 1993: 35).

Thus, the tourism policy often consisted in a 'freezing' of the selling price of the tourist package abroad, a measure which combined with the devaluation of the drachma and its continuous parity losses succeeded in securing a 'fictitious competitiveness' for the Greek package. This competitiveness, however, was seriously threatened each time there was an attempt at a substantial increase because of important rises in cost elements. (Kalogeropoulou, 1993: 2) 
Table 6 Structural problems and challenges

- Image of Greece as cheap, simple, unsophisticated, undifferentiated, sun-sea destination;

- Gradual deterioration of tourism product and lack of reinvestment in improvements;

- Increase of tourism arrivals but decrease of tourism expenditure per capita;

- Inadequacy of the Greek planning process;

- Dependence upon major tour operators for promotion and distribution;

- Plethora of anarchically developed and behaving SMTEs, aiming at short-term profitability;

- Inappropriate and ill-timed marketing campaign which has little effectiveness;

- Inadequacy of infrastructure to serve the ever-expanding demand;

- Lack of coordination at the destination and disrespect for tourists' needs;

- Lack of professionalism and training in both state and private tourism establishments;

- Individualistic behaviour by SMTEs and unwillingness to cooperate on a destination basis;

- Unsuccessful and inconsistent programmes of government intervention;

- Almost unregulated environment, with nearly complete lack of control;

- Political intervention which allows exception policies and employment of unqualified staff;

- Development of tourism as a single regional development option;

- Oversupply of tourism amenities and fierce price competition;

- Failure of the private sector to invest in long-term projects;

- Deterioration of natural, social and cultural resources;

- SMTEs' inability to resist in global concentration of the tourism industry;

- Inadequate distribution mechanisms which generate overdependence on intermediaries;

- Failure of both the private and public sectors to learn from internationally gained experience in tourism development and marketing;

- Lack of tourism research to identify the impacts of tourism;

- Negligence with regard to new tourism demand challenges.

The above issues illustrate that the Greek tourism product becomes increasingly incompetent. Hence, the inadequate 'product', 'promotion' and 'place' (distribution) elements of the tourism marketing mix reduce the willingness of prospective consumers to pay and has disastrous implications for the pricing policies, deteriorating the profitability of the SMTEs and the tourism economic impacts on the destination.

Ultimately the economic impacts of tourism in Greece become debatable, especially due to the inadequacy of tourism economic research and data, while the destination has to bear the environmental, social and cultural decay. Encouragingly, articles in recent tourism industry publications acknowledge these challenges and appreciate the dangers, urging both the private and public sector to take action (Touristiki Agora; Tourismos ke Oikonomia; Travel News; XENIA), as well 
as several influential members of the tourism industry (Josephides, 1993, 1994, 1995; Skoulas, 1994; Daskalantonakis, 1994; Divanis, 1994b; Plevris, 1995; Papandropoulos, 1995).

\section{Political intervention, limited research, lack of tourism policy and planning}

Perhaps the largest obstacle in developing a competitive tourism industry in Greece has been the inconsistent and irrational political intervention. Unfortunately, tourism has extensively been utilised as a political vehicle, where each government uses it to gratify its political needs and friends. This can be experienced in all levels of recruitment in the public sector institutions, as a change of government or even minister results in immense changes throughout the GNTO as well as to major policies and regulations. Thus, in the last 35 years (since 1966) the leadership of the GNTO has changed 28 times, allowing each General Secretary to stay in office for an average of 13.8 months. Political allies of each government use political pressure and intensive lobbying in order to achieve amendments in regulations, incentive policies and business environment. Hence the short-term profitability and commercial interests of the friends and political allies of each government often overrule the long-term strategy and set an improper example for the entire industry. These practices result in a great inconsistency in Greek tourism policy and disrupt its rationalisation. Therefore, a 'depolitisation of Greek tourism', towards a professionally managed public sector, guided through a compromised strategic Master Plan is urgently required (Josephides, 1995).

The limited existing scientific tourism research highlights the lack of comprehensive examination of tourism impacts in Greece, while it illustrates that tourism policy is based on insufficient documentation (Zacharatos, 1989: 278 and 1988: 22). Public sector research is almost non-existant, while the authorities seem uninterested in consulting the Greek-tourism research produced by academics (for example Zacharatos, 1984, 1986; Komilis, 1987; Loukissas, 1977; Papadimitris, 1988; Papadopoulos, 1985; Moore, 1992; Tsartas, 1989; Velissariou, 1991; Fotis, 1992; Buhalis, 1991, 1995, 2000c, Buhalis \& Diamantis, 2000), or the international tourism 'body of knowledge' (Zacharatos, 1988: 24). In addition, tourism consumption being characterised as a particular category of private consumption in the national accounts, it fails to reflect the real tourism impact on each economic sector. Thus, the process of collecting information for tourism expenditure in Greece prevents the assessment of tourism expenditure impacts on the national and regional economy and therefore cannot be used in drawing scientifically founded tourism policy (Zacharatos, 1989: 277; Konsolas \& Zacharatos, 1993: 58). Consequently, tourism policy follows conventional wisdom and concentrates on attracting a larger volume of tourists, ignoring scientific methods to assess the economic, social, cultural and environmental impacts of each tourism segment, assuming that the greater the tourism volume, the better for the national economy.

The lack of a comprehensive and rational tourism policy and planning or a Master Plan for Greek tourism is primarily responsible for the aforementioned structural problems. Policy is usually based on unsubstantiated statements published by the Tourism Ministry or the GNTO (GNTO, 1985b, 1989a, 1993) often as pre-election promotional material. In essence Greek authorities attempt to intervene aiming to stimulate arrivals, as well as to facilitate the operation and development of the 
Table 7 Greek tourism policy targets

- Development of demand;

- Training of tourism employees;

- Increase arrivals and foreign exchange income;

- Increase competitiveness of tourism product;

- Improvement of services in the industry;

- Reduction of seasonality and expansion of tourism season;

- Attraction of high spenders and alternative types of tourism;

- Construction of facilities appealing to the upper end of the market, such as luxury hotels, golf courses, congress centres, casinos and marinas;

- Development of tourism infrastructure, with emphasis on transportation;

- Support of social tourism for low-income domestic tourists;

- Geographical redistribution of tourism.

tourism industry. Based on the assumption that tourism arrivals to Greece would increase indefinitely, the general directions of the Greek tourism policy focus almost invariably on the targets summarised in Table 7 (Euromonitor, 1992: 61; GNTO, 1989b: 4.1 and 1993: 1; OECD, 1992: 70; Skoulas, 1985: 194; Leontidou, 1991: 88-91; Apostolopoulos, 1990; Zacharatos, 1989: 275 and 1988: 21).

However, as these tasks are not quantified and there is no time schedule or planning process for their achievement it is inevitable that their implementation and assessment is subject to irrationalities and personal judgement. Occasionally, incentives for tourism development; responses to lobbying from tourism-related associations and regions; training programmes; and general legislation attempt to direct the Greek tourism industry towards the described policy directions. In addition, an inconsistent and untargeted, promotional campaign is implemented yearly (Touloupas, 1996: 130). The campaign attempts to achieve the above unspecified policy tasks, while it is often a 'last minute' reaction measure to a forecasted decline of bookings for the current season, rather than a coordinated, long-term marketing policy (Jenner \& Smith 1993: 143; Papadopoulos, 1989: 304). Despite the advertising campaign's positive impact on arrivals, the feedback to the campaign is rather speculative, as no formal research is undertaken to identify the most cost-effective media and communication methods for each target market (Papadopoulos, 1989: 311 and 1987: 82).

Because the deficient scientific examination of Greek tourism and its impacts prevents the authorities from establishing quantifiable and measurable tourism policies, their policies are based on subjective and personal judgements, while feedback practices are rarely followed. In addition, the implementation of the vaguely defined tourism policy as well as the targets, regulations and standards are often bent to accommodate lobbying and political pressures (Zacharatos, 1989: 279). Komilis (1993: 225) suggests that tourism planning in Greece is generally realised and exercised within a socio-political environment characterised by several factors: a limited degree of political commitment; lack of social awareness and acceptability of planning actions; inadequacy of scientific and technical founda- 
tion to support planning intervention; and a centralised administrative-institutional system gathering a plethora of functions, but failing to perform its coordination and enforcing role. When the conflicting interests and power of each member of the tourism industry are brought into the equation, where different partners attempt to influence legislation in order to maximise their own short-term profitability, regardless of the impacts on the destination and other enterprises, the planning process becomes more complicated. This results in an ineffective planning system and process, which produces policies unable to provide an appropriate balance between restrictive policies and control planning implementation. Moreover, the plethora of SMTEs in combination with inadequate legislation concerning their establishment and operation, seem to affect adversely the competitiveness of the industry and the ability to diversify and enrich local tourism products (Komilis, 1992: 11; EIU, 1990: 59).

Consequently, several structural problems are originated, jeopardising the prosperity of both SMTEs and destinations, especially in overdeveloped regions. On the supply side, failure of the infrastructure to follow the dramatic expansion of the superstructure, in combination with the lack of solid institutional context of tourism policy and long-term regulation, result in the exploitation and inadequacy of environmental and socio-cultural resources, as well as the inability of the industry to generate the level of economic benefits desired and expected. On the tourism demand side, after the meteoric grow th in the 1970s and 1980s, the Greek tourism industry has been trying to transform 'the country into a destination which can compete not just on price, but on value for money' (EIU, 1990: 45). It is becoming apparent that the tourism population in not infinite and an adaptability and responsiveness to tourists' needs is of great importance (Sezer \& Harrison, 1994: 83).

\section{Structural problems jeopardise the profitability of the private sector}

Because of the aforementioned structural problems, most tourism industry enterprises are experiencing a decline in profitability. Hotels in particular are badly affected due to the high fixed assets, as well as their immobility and inflexibility which prevents them from adjusting to demand fluctuation. Several reasons determine their low profitability and inability to increase prices in line with inflation. The low occupancy levels achieved yearly is a key problem. Smith and Jenner (1995: 17) estimate that the 'year-round bed occupancy over the range of licensed accommodation is slightly under $30 \%$ '. As most of the properties are closed during the winter months due to the seasonality problems, they rely on three to six months to generate sufficient returns on their investment. The occupancy levels of accommodation establishments in Greek tourism are often determined by their co-operation with travel intermediaries. Based on the different seasonality patterns of different markets, rooms are normally allocated a year before the summer season to tour operators on 'allotment' or 'commitment' contracts which effectively determine the prices charged according to the security provided by tour operators for using and paying for hoteliers' rooms. Once the contracts are signed hoteliers effectively lose their control on their inventory and their right to market their rooms to other business sources before the release period (typically 7-14 days before arrival) in order to avoid overbooking. However, should their bookings fail to match their programme tour operators often utilise their buying power to cancel unwanted rooms at the beginning of the tourist season without paying compensation. Smaller 
hoteliers are often left with unoccupied rooms they which are unable to promote at the 'last minute' unless they drop their prices to unacceptable levels. As a result of their deficient intra-channel power, hotels often suffer a significant cut-back of their occupancy levels, which has direct implications for their profitability (Buhalis, 1995, 2000c: 460; Ktenas, 1996).

Similarly, the seasonality of the Mediterranean and Greek tourism industry has always been a problem for the profitability of SMTEs, since enterprises operate only for a limited period (Jenner \& Smith, 1993: 70; Drakatos, 1987; Donatos \& Zairis, 1991). Attempts to promote winter tourism by developing cultural and special interest tourism in the islands and winter sports in several ski resorts in Greece have proved fairly unsuccessful (EIU, 1986: 56). This is attributed to the image of Greece as an exclusively summer-sun destination, as well as to the uncoordinated attempts to maintain tourism enterprises active during the winter months (EIU, 1990: 57).

The average room rate is the second major determinant of hotel profitability. It is becoming apparent that employment costs and cost of capital, in combination with a relatively strong currency policy, reduce the ability of Greek accommodation establishments to offer competitive pricing and maintain their profitability. Marketing inadequacies and inability to promote the tourism product as a differentiated entity, the rapid increase of supply in comparison to demand, and the overall dependence upon the oligopsonistic tour operators for the Greek tourism product promotion, force hoteliers to accept contracts by tour operators which minimise their profit margin and adversely effect the quality of their product. Increasing levels of pressure by tour operators prevent SMTEs from renovating and investing in their properties and therefore a gradual deterioration of the properties is inevitable (Richter-Papaconstantinou 1992: 14, Skoulas, 1985: 189). European tour operators, faced with fierce competition in their markets, are essentially willing to pay an annual price increase equal to little less than the depreciation of the drachma, plus the inflation at the place of origin of the tourists (Ktenas, 1994). This policy progressively deteriorates the profitability of the Greek tourism industry and has severe impacts for its prosperity. The situation is worse for smaller accommodation establishments which manage to negotiate even smaller price increases, due to their exclusive dependence upon fewer intermediaries (Logothetis 1992: 14).

The oversupply of tourism services both in Greece and worldwide, also contributes to global competition for a less rapidly increasing demand (Josephides, 1993: 54). In Greece, the average annual increase of the official hotel bed supply in 1983-1992 was $4.7 \%$, while the annual average increase in international tourist bednights was 2.7\% (Epilogi, 1994: 271). The investment incentive Law 1262/82 boosted this oversupply as it generated small, infeasible and uncontrollable accommodation units, unable to offer high quality of services, while it increased the concentration of tourism units in infrastructure-undersupplied resorts (Kriebardis \& Marmagiolis, 1990: 51; Stavrou, 1989b:5). The vast majority of the capacity growth is on the 'illegal', unregistered, self-catering and self-serviced 'parahoteleria' sector, which provide very low quality and priced accommodation, and therefore, appeal to mass tour operators' clientele. This not only increases unfair competition for the officially registered hotels, but also reduces both tax revenues and employment at the macro level. 
Horwath (1994: 3) concludes that

unfortunately, the results in terms of return on investment in the tourism industry are not very promising especially when compared with those of other Greek economic sectors. It is an undisputable fact that the average Greek tourism entrepreneur is heavily dependent on the tourist package price which is strongly negotiated by the international tour operators. It is an 'unhealthy' dependency as a result of the weak position of the Greek tourist product in the international market. In addition, the aforementioned dependency is the result of the lack of marketing activities in an average tourist enterprise. As we all know, effective marketing activities are based on the product, place, price, promotion which all contribute to client satisfaction and further to a bigger share in the international tourist market. Up to now, three of the aforementioned important elements of marketing have been overlooked which determine the weak negotiation power of the Greek entrepreneur.

This situation has also resulted to several European companies expanding their operations into Greece or purchasing shares in Greek partners in order to improve their vertical integration. Should this vertical integration expand significantly, however, 'Greek tourism will be in fact controlled by foreign decision-making centres which will certainly operate on the basis of their own interests and not according to the overall interests of our national economy' (Kalogeropoulou, 1993: 2). Hence, radical measures are required immediately in product formulation, promotion strategy and distribution channels to support both Greek destinations and SMTEs to enhance their competitiveness, profitability and prosperity. Failure to react would have severe implications for the future of the Greek tourism private sector as the essence of its existence would be jeopardised, its costs may exceeding its returns.

\section{Structural problems generate negative tourism impacts}

In addition to the profitability problems of the private sector, the aforementioned structural problems have profound implications for the welfare of host populations in various Greek destinations, as their economic, social, cultural and environmental resources are exploited without ensuring their sustainability. Lack of comprehensive research and failure to initiate carrying-capacity limits or zoning systems contribute to the anarchic development of tourism, as well as expand negative impacts of tourism on local societies and environments. The following section highlights some of the costs Greek destinations are called to pay for their tourism activity, whilst it suggests that these issues should be addressed in the strategic planning process.

\section{Macro-economic negative impacts}

Despite the contribution of tourism to the Greek economy, certain potential risks can also be identified. Not only is the competitiveness and profitability of the tourism industry jeopardised, but also several destination regions seem to follow a policy of developing tourism at the expense of industrial and agricultural growth (Stavrou, 1989a: 6; Vernicos, 1987: 105). Instead of tourism stimulating agriculture, it seems that it hastens its decline, as the two economic activities 
compete for land and labour. The lack of structural investments in industrial or agricultural sectors, combined with the popularity of tourism professions in the workforce, endanger the balance of the regional economy, while reducing the tourism multipliers (Briassoulis, 1993: 295). As a result, the economic structure of the destination is jeopardised, while a complete dependence upon tourism becomes inevitable (Komilis, 1992: 7). Both opportunity costs and displacement effects are therefore evident. Moreover, there is evidence that the progress of destinations through their life-cycle, and especially the introduction of mass tourism, decreases their economic impacts, while it makes local control of the industry far more difficult (Loukissas, 1982: 537). 'Because of the high degree of dependence of Greek tourist enterprises on tour operators, the actual amount of tourist spending remaining in the country is only the $40-50 \%$ of total tourist spending' (Briassoulis, 1993: 296). Public-sector subsidies to the private sector, in various forms such as incentives, cooperative marketing campaigns and unemployment benefits in the off-season as well as tax evasion and 'paraeconomy' also reduce the real benefit at the macro level (Mourdoukoutas, 1988; Drakatos, 1987; Leontidou, 1991: 102). Lack of scientific research, on the economic impacts of tourism makes the real contribution of tourism in the economy speculative, rather than based on hard evidence (Zacharatos, 1988, 1989; Konsolas \& Zacharatos, 1993).

\section{Social and cultural negative impacts}

The development of mass tourism and the lack of effective planning and management are also responsible for a number of negative social and cultural impacts observed in Greek host societies (Tsartas, 1989, 1992; Stavrou, 1978, $1979,1980,1986 b)$. Although the degree of interaction of the population with tourists depends heavily on the geomorphology of destinations and the location of resorts (Loukissas, 1982: 538), tourists' behaviour is often offensive to the host population, but tolerated due to the economic benefits (CastelbergKoulma, 1991: 201; Kousis, 1989; Wickens, 1994: 823). Most Greek tourism destinations are almost crime-free zones during the winter, due to the small population and personal relationships of locals. Tourism, however, introduces several types of criminal activity, often unknown to local people. As police forces are usually allocated according to needs of the permanent population in a destination, they are often incapable of handling the demands of the summer months and are unable to deal with visitors' misbehaviour such as hooliganism and 'lager-looting'.

The commercialisation of history, cultural traditions and the Greek lifestyle is a phenomenon met in several destinations. This regrettably affects the renowned Greek hospitality, commercialises human relations with tourists and reduces the ties of solidarity and cooperation between locals, since they compete for the tourism market (Papadopoulos, 1988b: 24). As the average employee works 60.5 hours weekly for 29.5 weeks a year, there is little time left for social, religious and cultural obligations during the season (Mourdoukoutas, 1988: 325). Although a certain degree of 'demonstration effect' and 'xenomania' can be attributed to tourism, the country is equally influenced by the mass media as well as by the Greek students and professionals living abroad (Papadopoulos, 1988a: 30; Wickens, 1994: 822). Moore (1995) also explains that tourism not only has had a 
contribution to the increase of alcohol consumption by Greeks, but has also shifted their taste away from locally produced wine to imported spirits and beer. Briassoulis (1993: 296) perhaps describes best the change in labour force values when as she suggests that tourism has created a

peculiar parasitic group of tourist entrepreneurs operating tourist-serving enterprises, like tavernas, cafeterias etc., the principal characteristics of which are high profits and tax evasion. Consequently, a particular personality type is created: the 'successful' entrepreneur who earns a lot with little work, has a rich erotic life and is professionally independent (in contrast to public and private employees). This model is followed by many young people who abandon other productive, year-round occupations, 'work' only during the tourist season, stay idle for the rest of the year and eventually, suffer from the volatility of the tourist market.

The family relations and values are therefore under great transition and perhaps threat (Castelberg-Koulma, 1991: 201; Kousis, 1989; Moore, 1992).

\section{Negative environmental impacts}

Despite environmental resources becoming central to destinations' competitiveness, most Greek destinations go through an unparalleled exploitation due to inadequate planning and reinvestment in their sustainability, jeopardising their future (Buhalis \& Fletcher, 1995). Boniface and Cooper (1994: 141) suggest that geographical concentration of tourism

has led to the view that Greece will become saturated with tourists and that damage will be done to the environment and cultural heritage in the more popular areas. Already the environment has suffered from haphazard, uncontrolled building, and pollution of the sea and the flora and fauna are being effected by waste disposal.

Coastal pollution, water shortages, sewage treatment, waste disposal, traffic congestion, noise pollution, overbuilding, and aesthetic degradation are some of the impacts experienced already in a number of resorts (Briassoulis, 1993: 297; Coccosis \& Parprairis, 1992; Peterson, 1990; Marinos, 1983; Stavrou, 1988: 19 and 1989a: 5; Papadopoulos, 1988b: 24). Most of the islands also face water shortage due to the inability of natural supplies to provide sufficient water for the tourism demand. Imported mineral water from the mainland is an expensive way to solve this problem due to the transportation cost, while it creates more waste and environmental damage. In addition, the destruction of endangered species' habitats is another problem experienced on several islands (Zakynthos: Caretta-Caretta and Allonissos: monk-seals) (Ottaway, 1992; Van Den Bergh, 1993: 70; Prurier et al., 1993). Urgent coordination with all tourism actors at the local level is essential, while regulation is required to set objective and measurable limits and targets, in order to preserve local environmental resources. Financial difficulties in the industry only exacerbate these impacts as the private and public sectors feel unable to reinvest in the conservation of resources.

The aforementioned negative impacts emerge as a result of the structural problems of the Greek tourism industry and illustrate that the mass tourism orientation of the industry reduces the sovereignty of the host population over 
their land and resources whilst jeopardising their expected benefits and future welfare. As these impacts are trade-offs for the economic gains of the tourism activity, it is important that consistent, long-term strategic planning should be undertaken in order to enable the preservation of the local resources and achieve sustainability at tourism destinations. These tasks should all be reinforced by research, political will and strategic planning.

\section{Where Do We Need to Go and How Are We Going There? Towards Strengthening the Competitiveness of Greek Tourism and SMTES}

Based on the situation analysis, as well as on the strategic weaknesses and structural problems, the paper attempts to provide a framework for strategic planning which will enable the strengthening of the competitiveness of Greek tourism and SMTEs. Porter (1985: 1) suggests that competitive strategy 'is the search for a favourable competitive position in an industry' which is a function of the attractiveness of the industry and the relative competitive position within that particular industry. He also argues that 'competitive strategy aims to establish a profitable and sustainable position against the forces that determine industry competition'. Competitiveness is, therefore, defined as the effort undertaken by organisations to maintain long-term profitability, above the average of the particular industry within which they operate or above alternative investment opportunities in other industries.

Traditionally, the tourism industry in the majority of destinations worldwide is based on a network of SMTEs which provide all types of tourism products and services, while enabling closer interaction between the host population and visitors, as well as facilitating a rapid infusion of tourism spending into the local economy. As 'tourists' overall experience is composed of numerous small encounters with a variety of tourism service providers' (Moutinho, 1990: 104), there is a great overlap between the customer perception of local SMTEs and destinations, which makes them almost indistinguishable. Consequently the competitiveness and prosperity of destinations and SMTEs are closely interrelated, as the fortune of the one depends heavily upon the management and competitiveness of the other. Therefore the generic strategy for destinations involves SMTEs and vice versa.

\section{Grand strategy: Strategy formulation for Greek tourism and SMTEs}

Based on the strategic analysis, a grand strategy is proposed for the Greek tourism industry and SMTEs, in order to demonstrate the directions the destinations should follow in their attempt to increase their competitiveness and reduce their vulnerability. As different resorts, destinations and SMTEs have dissimilar needs only generic strategies can be drawn. However, these guidelines can be applicable to destinations and SMTEs worldwide as they address strategic rather than operational issues. The analysis is based on the assumption that SMTEs formulate leisure value-added chains or networks of wealth creation, which essentially comprise the entire destination. Therefore, an integrated approach is followed, as there is a great complementarity between the strategies and strategic directions for both the Greek tourism industry and SMTEs. 


\begin{tabular}{|c|c|c|c|}
\hline & \multicolumn{2}{|c|}{ STRATEGIC ADVANTAGE } \\
\hline & & Perceived product uniqueness & Cost advantage \\
\hline \multirow{2}{*}{$\begin{array}{l}\text { TARGET } \\
\text { MARKET }\end{array}$} & $\begin{array}{l}\text { Industry } \\
\text { wide }\end{array}$ & - Differentiation & - Cost Leadership \\
\hline & $\begin{array}{l}\text { Particular } \\
\text { segments } \\
\text { only }\end{array}$ & - Differentiation Focus & - Cost Focus \\
\hline
\end{tabular}

Figure 1 Porter's three generic strategies

Source: Porter, 1980: 39

The grand strategy analysis is based on an examination of three general strategy models, namely Porter's generic strategies, Gilbert's proposition for 'differentiation of the destination' and Poon's analysis for 'flexible specialisation'. A grand strategy is then proposed for both Greek tourism and SMTEs, based on inference emerging from these three models. Figure 1 illustrates the three main generic strategies proposed by Porter (1980:34-46) in order to 'outperform other firms in an industry': overall cost leadership, where the firm is required to minimise its costs, based on mass production and strict cost control of the main business functions; differentiation of products or services by 'creating something that is perceived industry-wide as being unique'; or focus on a 'particular buyer group, segment of the product line or geographical market' and achieve either cost leadership or product differentiation (Porter, 1980: 37-8).

Furthermore, Gilbert $(1984,1990)$ argues that destinations should differentiate their tourism products in order to be able to achieve a unique 'tourist product benefit' which would enable them to establish their position in the international tourism market, as well as to attract high spenders and loyal tourists. Tourism destinations, therefore, should attempt to achieve a 'status area' image, rather than a 'commodity area' one, as illustrated in Figure 2. In the first case, the destination is heavily substitutable, very sensitive to price and economic changes, while consumers have a low awareness of any unique benefits or attributes of the region. Thus, holidaymakers base their decision to visit the area merely on price, while the demand for the destination is incidental and destinations are unable to attract high spenders. In contrast 'status areas' achieve intentional demand as a result of the unique product attributes perceived by the tourism market. These unique attributes may be genuine or imagined and thus, a destination is regarded as irreplaceable increasing consumers' loyalty and willingness to pay. Gilbert (1990: 24-5) asserts that destinations should attempt to become 'status areas' in order to improve their image, loyalty and economic benefits.

A third strategic approach is proposed by Poon $(1987,1988,1989,1990,1993)$, based on the concept of 'flexible specialisation' of the tourism business. In essence, Poon examines the industry processes and proposes a strategy to enable tourism organisations to improve their competitiveness. Poon argues that 'flexible specialisation' is a strategy of 'permanent innovation' and 'ceaseless change' which provides for the 'new tourism'. This new tourism is flexible, segmented, customised to the tourist's needs and diagonally integrated. In contrast, the old tourism can be characterised as 'mass, standardised and rigidly packaged' (Poon, 1989: 91-3). 
The main sources of flexibility for service firms lie in the organisation, management, marketing, distribution and other forms of interaction and interrelationships among guests, hotels, suppliers, distributors. What is important however is not each of these stand alone aspects but how they are coupled to create competitive advantages and hence, capabilities to move with the market. (Poon, 1988: 24)

Examination of these three main strategies illustrates that they share a similar base. Porter's 'differentiation', Gilbert's 'status area' and Poon's 'flexible specialisation' describe the attempt undertaken by firms and tourist destinations to achieve value competitive advantages. In contrast, the 'cost leadership', 'commodity area' and the 'standardisation or Fordism production model' describe the effort to achieve 'cost competitive advantage', where destinations and SMTEs offer their products for less than their competitors. In the first case, consumers perceive the product as unique and are willing to pay a premium, while in the second case, the decision is merely based on price. Thus the classical strategic decision of 'low volume-high profit margin' or 'high volume-low profit margin' is the underlying concept of the two alternative strategies.

Both Gilbert and Poon agree that destinations should aim to achieve 'status area' or niche orientation, through differentiation, in order to increase consumer satisfaction as well as to maximise the benefits for both regions and SMTEs. As a result, Greek tourism and SMTEs need to focus towards the differentiation strategy, define their niche markets and serve them accordingly. This strategy is already adopted in several resort areas, such as Valencia in Spain, where it is recognised that the need for diversification and differentiation 'has now become essential owing to the level of competitiveness that has been attained (and can be foreseen) in the world tourist market' (Fayos-Sola, 1992: 49). Differentiation is also particularly useful for insular destinations in microstates, where a limited number of economic and financial resources are available (Wilkinson, 1989: 170). As most destinations consist of SMTEs, networks, there is an overlap between their strategic orientations, and therefore the above analysis is applicable to both the Greek tourism industry and SMTEs.

Destinations implementing a 'status area' strategy can enhance the satisfaction of tourists, as well as their competitiveness. The formulation of unique and

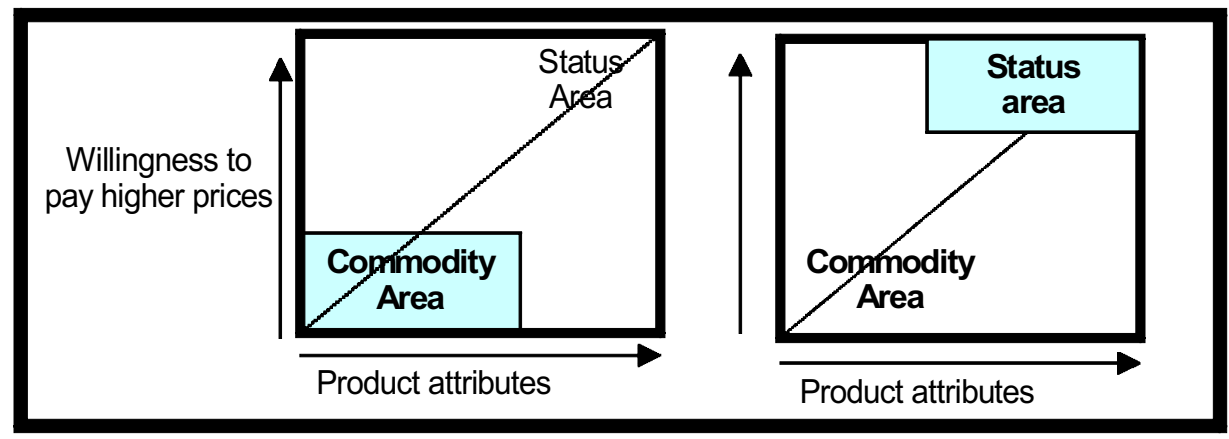

Figure 2 Gilbert's differentiation strategy

Source: Adapted from Gilbert 1990, 25 
customised products by using flexibility and cooperation also increases tourists' willingness to pay and wins their loyalty, while it responds to the new tourism demand trends. However, the proposed strategy should not be seen as an excuse for SMTEs and destinations not to attempt to improve their efficiency and minimise their production costs. Although the unique service for tourists' needs should be their priority, offering perceived value for money would determine their competitiveness in the marketplace. As a result, all Greek resorts and SMTEs should assess their assets and strengths for serving specific target markets, taking advantage of their small size which facilitates flexibility and specialisation.

It is quite apparent that the cost advantage strategy has to be avoided in management of tourism destinations, as regions need to preserve their scarce environmental and sociocultural resources and achieve sustainable development. As cost advantage is based on mass production and consumption, it assumes an unlimited production capacity, which is inapplicable in the tourism industry. The inseparability of the tourism product determines that consumers should be present at the time of product delivery, and when combined with tourism seasonality, it generates demand peaks, which drain destinations' scarce environmental, sociocultural resources. The 'high volume-low profit margin' strategy has therefore harmful social and environmental impacts on destinations. Destinations have maximum carrying capacities beyond which both the welfare of local populations and the satisfaction of tourists are jeopardised. Although economic benefits can also be achieved by using the 'commodity area' or the 'standard product model', it is argued that these approaches reduce tourists' satisfaction and their willingness to pay, and are opposed to the demand trend towards individualisation.

Unfortunately, however, some destinations can no longer be positioned as irreplaceable unique products, due to their overdevelopment. Tourism supply has exceeded the carrying capacity of these resorts, and their product has reached the saturation or decline phase of their life-cycle. Several Spanish costas and some Greek resorts, such as Benitses, Kavos, Faliraki, Malia, Hersonissos, and Nidri (Josephides, 1994), have been overdeveloped to such an extent that only a 'high-volume, low-profit margin' strategy is feasible. When resorts reach their saturation level only a 'cost leadership' or 'mass production' strategy can be proposed, as they are unable to provide any specific 'tourist product benefit'. The attraction of the lower end of the market is inevitable and as a consequence, there are no alternative strategies. The minimisation of further sociocultural and environmental damage, as well as attempts to improve the surrounding environment, should also be a primary objective of both tourism destinations and SMTEs in this case. The ultimate aim should be to regenerate the resources of the area and to relaunch the tourism destination to attract specific markets which will be willing to pay a higher price for the destination.

\section{Strategic directions, objectives and tasks for Greek tourism and SMTEs}

Table 8 presents three pivotal strategic directions which are identified in order to stimulate the competitiveness of both Greek tourism and SMTEs. This section illustrates how the aforementioned grand strategy can be implemented for tourist destinations and SMTEs, through a number of strategic directions, objectives and tasks, as presented in Table 9. 
Table 8 Pivotal strategic dimensions for Greek tourism

(1) Enhance the satisfaction of tourists and delight the customer;

(2) Strengthen the long-term profitability and competitiveness of Greek tourism and SMTEs;

(3) Develop Greek destinations sustainably, and ensure prosperity of host population.

Enhancing the satisfaction of tourists and delighting the customer are pivotal to ensuring the well-being of Greek destinations and SMTEs in the long term and thus, the entire range of tourism service providers should aim to delight their clients. As a result of the tourism product integration, consumer satisfaction cannot be achieved by independent businesses separately, but by the entire network of SMTEs in Greek destinations. The improvement in services is perhaps the most important strategic objective. Consistency of promises through standardisation of service delivery and implementation of a total quality management philosophy throughout the industry are essential strategic tasks for achieving this objective, while flexibility in service delivery and improvements in training are critical. In line with the grand strategy, the production of tailor-made tourism products should be ensured in order to satisfy the specific needs of particular niches and the requirements of the emerging new tourism demand. Product augmentation would enable also the Greek tourism product to exceed the expectations of consumers and hence enhance their satisfaction. Life style segmentation would enable Greek tourism and SMTEs to design appropriate tourism products. As tourist demand elasticity has increasingly become doubtful in recent years, the price of the holiday is no longer considered to be the most important attribute in the decision-making process. Consequently, the Greek tourism industry should concentrate on providing value for money at all price levels, as well as offering at least whatever they have promised to the consumer.

Supporting the long-term competitiveness and profitability of Greek tourism and SMTEs is by far the most important strategic objective for the tourism industry. The first strategic objective for every SMTE has to be the increase in revenue, by maximising its occupancy or load factors and the rates it achieves. The lengthening of the operating season, as well as the identification of new markets and the penetration into existing ones, and the effective utilisation of distribution channels, will contribute to this strategic direction. Higher rates can be achieved by targeting specialised and smaller tour operators, attracting alternative types of tourists and expanding the distribution channels mix as well as by attempting a certain degree of 'disintermediation' by encouraging direct sales to outgoing travel agencies or consumers. Aggressive marketing and establishment of partnerships with other enterprises should be essential functions of Greek tourism and SMTEs. Motivation of 'front-of-house' employees as salesmen and sale incentives would also increase average spending per customer. The use of CRSs and destination management systems may also be an appropriate method for achieving higher prices and better occupancy rates (Buhalis, 1994). Finally, yield management techniques should be utilised by all types of SMTEs to assist them in pricing and maximising revenue. Cost control 
Table 9 Strategic directions, objectives and tasks for SMTEs and destinations

\begin{tabular}{|c|c|c|}
\hline Strategic directions & Strategic objectives & Strategic tasks \\
\hline \multirow[t]{3}{*}{$\begin{array}{l}\text { 1. Enhance the sat- } \\
\text { isfaction of tour- } \\
\text { ists and delight } \\
\text { the customer }\end{array}$} & 1.1 Improvement of services & $\begin{array}{l}\text { a. Standardisation of service de- } \\
\text { livery } \\
\text { b. Development of quality control } \\
\text { systems } \\
\text { c. Consistency of promises } \\
\text { d. Improvements in operational } \\
\text { management } \\
\text { e. Flexibility in services delivery } \\
\text { f. Training and education im- } \\
\text { provements } \\
\text { g. Smile and personal relation- } \\
\text { ships } \\
\text { h. Augmentation of tourism } \\
\text { product } \\
\text { i. Total quality management }\end{array}$ \\
\hline & $\begin{array}{l}1.2 \text { Specialisation of tourism } \\
\text { product }\end{array}$ & $\begin{array}{l}\text { a. Niche marketing } \\
\text { b. Lifestyle targeting }\end{array}$ \\
\hline & 1.3 Value for money & a. Quality at each price level \\
\hline \multirow[t]{3}{*}{$\begin{array}{l}\text { 2. Strengthen the } \\
\text { long-term com- } \\
\text { petitiveness and } \\
\text { profitability of } \\
\text { Greek tourism } \\
\text { and SMTEs }\end{array}$} & 2.1 Increase revenue & $\begin{array}{l}\text { a. Increase tourist volumes } \\
\text { b. Target new markets and pene- } \\
\text { tration in existing markets } \\
\text { c. Use yield management } \\
\text { d. Expand distribution channel } \\
\text { mix } \\
\text { e. Aggressive marketing } \\
\text { f. Achieve high average spending } \\
\text { per customer } \\
\text { g. Select high-quality specialised } \\
\text { tour operators } \\
\text { h. Attract alternative types of } \\
\text { tourism } \\
\text { i. Use alternative distribution } \\
\text { channels } \\
\text { j. Motivate front-of-house em- } \\
\text { ployees as salesmen }\end{array}$ \\
\hline & $\begin{array}{l}\text { 2.2 Cost control and rational } \\
\text { management }\end{array}$ & $\begin{array}{l}\text { a. Standardise service delivery } \\
\text { b. Increase productivity } \\
\text { c. Reduce labour costs } \\
\text { d. Rationalise supplies manage- } \\
\text { ment } \\
\text { e. Education/training for manag- } \\
\text { ers and employees } \\
\text { f. Use of new technology } \\
\text { g. Integrate service delivery } \\
\text { within SMTEs }\end{array}$ \\
\hline & $\begin{array}{l}\text { 2.3 Human resources man- } \\
\text { agement }\end{array}$ & $\begin{array}{l}\text { a. Internal marketing } \\
\text { b. Empowerment } \\
\text { c. Satisfactory salary and working } \\
\text { conditions } \\
\text { d. Long-term relations with em- } \\
\text { ployees } \\
\text { e. Motivation and rewards }\end{array}$ \\
\hline
\end{tabular}


Table 9 (cont.) Strategic directions, objectives and tasks for SMTEs and destinations

\begin{tabular}{|c|c|c|}
\hline & $\begin{array}{l}2.4 \text { State and public tourism } \\
\text { organisation support }\end{array}$ & $\begin{array}{l}\text { a. Destination development and } \\
\text { control } \\
\text { b. Incentives policies for improve- } \\
\text { ment } \\
\text { c. Attract European Union assis- } \\
\text { tance } \\
\text { d. Promotional activity } \\
\text { e. Provide financial resources }\end{array}$ \\
\hline \multirow[t]{5}{*}{$\begin{array}{l}\text { 3. Develop Greek } \\
\text { destinations } \\
\text { sustainably, and } \\
\text { ensure prosper- } \\
\text { ity of host popu- } \\
\text { lation }\end{array}$} & 3.1 Environmental protection & $\begin{array}{l}\text { a. Carrying capacity identification } \\
\text { b. Zoning system application } \\
\text { c. Architecture preservation } \\
\text { d. Installation of sewage treat- } \\
\text { ment systems } \\
\text { e. Reduction of noise pollution } \\
\text { f. Natural supplies management }\end{array}$ \\
\hline & $\begin{array}{l}3.2 \text { Infrastructure ameliora- } \\
\text { tion }\end{array}$ & $\begin{array}{l}\text { a. Accessibility improvements } \\
\text { b. Telecommunication improve- } \\
\text { ments } \\
\text { c. Public facilities advancements }\end{array}$ \\
\hline & $\begin{array}{l}\text { 3.3 Transportation improve- } \\
\text { ments }\end{array}$ & $\begin{array}{l}\text { a. Improvement of local timeta- } \\
\text { bles } \\
\text { b. Punctuality and reliability } \\
\text { c. Improvements of vehicles } \\
\text { d. Flexibility to meet demand } \\
\text { needs }\end{array}$ \\
\hline & 3.4 Economic integration & $\begin{array}{l}\text { a. Integration with raw material } \\
\text { production } \\
\text { b. Utilisation of local labour force } \\
\text { c. Integration of tourism services } \\
\text { d. Diagonal integration of destina- } \\
\text { tion's economy }\end{array}$ \\
\hline & $\begin{array}{l}\text { 3.5 Equitable return on re- } \\
\text { sources utilised }\end{array}$ & $\begin{array}{l}\text { a. Establish mechanism for } \\
\text { reinvestments } \\
\text { b. Provide services for host } \\
\text { community } \\
\text { c. Invest in sustainability of } \\
\text { resources } \\
\text { d. Ensure equity in distribution } \\
\text { of wealth produced }\end{array}$ \\
\hline
\end{tabular}

Source: Adapted from Buhalis 1991: 83a.

and rational management is the second strategic objective needed to increase efficiency and profitability of both Greek destinations and SMTEs in the long term. Standardisation of the service delivery process and minimisation of the labour cost through better operational management would be primary recommendations. Managers and employees should improve their productivity and marketing skills by intensive training. In addition, the rationalisation of supply management and the use of new technology is expected to reduce operational costs. Finally, integration of service delivery enables SMTEs to provide complementary services and achieve additional revenues without immense costs. 
Human resources management is crucial in the delivery process of tourism products. The concept of 'internal marketing', where employees are perceived and treated as 'internal customers' has to be utilised in order to ensure their satisfaction. As Berry (1981:34) states 'the satisfaction of the needs and wants of the internal customers can upgrade their capacity for satisfying the needs and wants of their external customers' and as a consequence, it can contribute to the competitiveness and profitability of Greek tourism and SMTEs. Satisfactory salary and working conditions are prerequisites for the well-being of SMTEs' employees. Long-term relationships between employees and SMTEs minimise turnover, enabling a better performance, while they reduce recruitment and training costs. Empowerment would enable employees to be involved in the management of SMTEs and authorise them to respond more efficiently to consumer requests, while contributing to their job satisfaction. Finally, the support of the GNTO is vital for the long-term survival of SMTEs. Apart from the improvement in infrastructure, the GNTO is expected to hold the strategic responsibility of the destination, as well as to regulate the competition in order to enable smaller enterprises to survive. Incentive policies need to reflect the specific requirements of each resort and enable development or improvement of certain types of enterprises. The GNTO is also instrumental in attracting assistance from European development funds while it should also coordinate the majority of Greek tourism promotional activity. A promotional mix which maximises the effectiveness of the communication message needs to be drawn, while budgets need to be available at the time consumers go through their decision-making process in order to influence their choice of destination. Finally, the need for the public sector to provide affordable financial resources for SMTEs is highlighted by the EU (EC, 1993b: 73).

The third strategic direction for Greek tourism and SMTEs should be the sustainable development of destinations and local areas, not only for the host population but also because this is vital for both consumer satisfaction and the profitability of SMTEs. Although in most cases SMTEs are unable to incorporate these types of strategic objectives and tasks on their own, they can initiate a framework of necessary actions for sustainable destination development through their associations. Environmental protection is naturally the most important strategic objective as consumers' environmental consciousness has been raised recently. Carrying capacity limits should be identified and strict regulations and guidelines for tourism development need to be drawn. A zoning system should be implemented in order to locate tourism activities according to the geographical morphology of the destination. In addition, natural resources management is necessary, as tourism demand may exhaust the resources and especially the water supplies. The installation of sewage treatment systems and the reduction of noise pollution should be considered especially for resorts which suffer the consequences of these problems. In addition, infrastructure amelioration must be one of the primary objectives, as it is an essential prerequisite for both consumers' satisfaction and SMTEs' development. The improvement of accessibility, public services, as well as telecommunications facilities is a crucial factor. Transportation is also significant in increasing both consumer satisfaction and profitability of SMTEs, as it determines whether consumers can access the destination easily, while it also provides the first impression to tour- 
ists. Improvements of timetables, and services, reliability; increasing transportation capacity; and an enhancement of the fleet in terms of speed, cleanliness and leisure facilities are all required. Furthermore, greater flexibility is needed by transportation operators in order to meet demand needs. Economic integration can improve the economic and social benefits of tourism in the region and the efficiency of SMTEs. Ultimately tourism should be utilised as the catalyst and major stimulant for regional development. Tourism enterprises should make every effort to use local raw materials and labour, in order to maximise the multiplier effects within Greece. Diagonal integration of destinations' economy can be achieved by rearranging the goods and service production in order to support the tourism industry demand, and thus minimise imports. Finally, SMTEs and tourism organisations need to offer a fair return-on-resources utilised back to the host community. A mechanism should be established in order to reinvest part of the revenues in the sustainability of resources; provide services for the host community, such as education, training, health services; and generally ensure equity in distribution of wealth produced from local resources. As the private sector cannot be expected to behave altruistically towards the host community, the GNTO and other public-sector departments should probably utilise regulation and taxation for this purpose.

\section{Conclusion: Greek Tourism Needs a Long Overdue Master Plan and Comprehensive Policy}

The emerging international tourism competition; the hitherto mass tourism orientation of the industry; the transformation of demand; the development of the volume of tourists visiting; the dependence upon intermediaries for the distribution of the tourism product in the major target markets; the lack of a wide range of managerial skills by Greek tourism entrepreneurs; and the lack of a comprehensive tourism policy or Master Plan by the public sector has led the competitiveness of Greece tourism to decline. This has several unfavourable implications for the profitability of the private sector as well as numerous negative economic, sociocultural and environmental impacts for the host population. As a result the return on resources utilised for the production of Greek tourism services is inadequate and the sustainability of Greece as a major tourism destination is rapidly becoming doubtful. Based on a strategic analysis, the paper illuminates the strategic weaknesses and structural problems of both the private and public sectors, and demonstrates that a rationalisation of the tourism industry is urgently required. Consequently, a grand strategy as well as a wide range of strategic directions, objectives and tasks are proposed for both Greece as an entity and its SMTEs. Although no quantitative targets are set in this paper, it is expected that each destination will analyse its resources and adapt its strategic planning accordingly.

The GNTO is urged to rationalise its strategy and to draw up a Master Plan and a comprehensive strategy for the entire country and for each resort, where a strategy would be adopted based on quantifiable objectives and tasks. Extensive research needs to be undertaken by using credible measurement methodologies, such as Input-Output models and multipliers analysis, not only for the economic, but also for the social, cultural and environmental impacts (Zacharatos, 1988, 1989; Buhalis 
\& Fletcher, 1995). A holistic tourism management system is demanded to facilitate the development and implementation of the tourism strategy, through funds allocation and monitoring, land use control, and examination of tourism public- and private-sector practices. A thorough examination of tourism impacts in each region would be a prerequisite for tourism planning as it will establish and provide scientific backing to strategic targets. Komilis (1994: 71) explains that although the various levels of planning (sectoral, national/EU, spatial or regional) are not mutually exclusive, but rather complementary, the regional level planning is more suitable for drawing sustainable strategies, especially for areas with dissimilar needs like the Greek destinations. The regional planning should 'contribute to the maximisation of regional development benefits in a way that utilises and mobilises the regional resource base, realises regional inter-sectoral linkages and is compatible with regional economic interests, societal values and environmental assets'. It should also take into consideration the uniqueness of insular economies, as well as the cultural and environmental resources of each particular region and the complexity of rural and urban functions. The planning process should encourage the complementarity and coexistence of economic activities, rather than promote sectoral separation and single-sector developments. In addition, it needs to improve the balance between regional self-sufficiency and dependence upon external inputs and finally it should promote integration within the European Union.

The public sector has to play its long overdue role as regulator, coordinator, infrastructure provider and promoter of the destination, while a multi-integration of the tourism industry, with all the involved bodies in the preparation, distribution and delivery of the tourism experience, needs to be ensured (Wanhill, 1993; Hall, 1994; Skoulas, 1994: 10; Stavrou, 1988: 46). The private sector also has an important role to play as it should improve the Greek tourism industry competitiveness by improving its managerial and labour force competencies, enhancing the quality of services, designing appropriate marketing mixes to attract and satisfy target markets and cooperating closely in order to achieve synergies and economies of scale (Briassoulis, 1993: 300; Cooper \& Buhalis, 1992). To reverse the vicious circle of decreasing quality is of critical importance for the Greek tourism industry. Better quality services would stimulate the competitiveness of the Greek tourism product, strengthen its position in the international market, provide principals with distribution channel power, enhance its customers' willingness to pay and enable the industry to increase its prices, improving the profitability at the micro level and the economic impacts of tourism at the macrolevel. Ultimately a diagonal integration strategy for both Greek tourism and SMTEs should aim to delight consumers, enhance the long-term prosperity of SMTEs, and improve the welfare of the host populations. The Olympic Games in 2004 offer a unique opportunity to regenerate and rebrand Greek tourism, a cause which the entire industry should champion!

\section{The Author}

Dimitrios Buhalis is Senior Lecturer and course leader MSc in tourism at the University of Surrey. He holds a BBA from the University of the Aegean as well as an MSc and a PhD in tourism management from the University of Surrey. His research interests focus on information systems and technology, strategic 
management, distribution channels of tourism, destination management and planning and destination integrated computer information reservation management systems.

\section{Acknowledgements}

The author would like to acknowledge Prof. C. Cooper and Prof. J. Fletcher for their invaluable contribution to this research. Financial support from the Surrey Research Group, ConTours Consultants, as well as field research sponsorships by the University of Surrey, the Greek National Tourism Organisation and the University of the Aegean are gratefully appreciated.

\section{Note}

1. An earlier version of this paper was published as a monograph, Planning/Development by the International Centre for Research and Studies in Tourism, Aix-en-Provence, France.

\section{Correspondence}

Any correspondence should be directed to Dr Dimitrios Buhalis, Senior Lecturer in Business Information Management SMSSS, University of Surrey, Guildford GU2 7XH, UK (d.buhalis@surrey.ac.uk).

\section{References}

Apostolopoulos, T. (1990) New strategy of tourism development (in Greek). Tourism and Economy (November), 228-38.

Berry, C. (1981) The employee as customer. Journal of Retail Banking 3, 33-40.

Boniface, B. and Cooper, C. (1994) The Geography of Travel and Tourism (2nd edn). London: Heinemann.

Briassoulis, H. (1993) Tourism in Greece. In W. Pompl and P. Lavery (eds) Tourism in Europe: Structures and Developments (pp.285-301). Oxford: CAB International.

Buckley, P. and Papadopoulos, S. (1986) Marketing Greek tourism: The planning process. Tourism Management 7, 86-100.

Buhalis, D. (1991) Strategic marketing and management for the small and medium tourism enterprises in the periphery of the European Community. A case study for the Aegean islands in Greece, MSc Dissertation, University of Surrey, Guildford.

Buhalis, D. (1994) Information and telecommunications technologies as a strategic tool for small and medium tourism enterprises in the contemporary business environment. In A. Seaton et al. (eds) Tourism - The State of the Art: The Strathclyde Symposium (pp. 254-75). England: J. Wiley and Sons.

Buhalis, D. (1995) The impact of information telecommunications technologies on tourism distribution channels: Implications for the small and medium sized tourism enterprises' strategic management and marketing. PhD Dissertation, University of Surrey, Guildford.

Buhalis, D. (2000a) Marketing the competitive destination of the future. Tourism Management (Special Issue - The Competitive Destination) 21 (1), 97-116.

Buhalis, D. (2000b) (forthcoming) Athens, Tourism-Travel Intelligence. London.

Buhalis, D. (2000c) Relationships in the distribution channel of tourism: Conflicts between hoteliers and tour operators in the Mediterranean region. Journal of International Hospitality, Leisure and Tourism Adminstration 1 (1), 113-39.

Buhalis, D. and Diamantis, D. (2001, forthcoming) Tourism development and sustainability on the Greek archipelagos. In G. Apostolopoulos and D. Ioannides (eds) Tourism in the Mediterranean. Routledge. 
Buhalis, D. and Fletcher, J. (1995) Environmental impacts on tourism destinations: An economic analysis. In H. Coccosis and P. Nijkamp (eds) Sustainable Tourism Development (pp. 3-25). London: Avebury.

Camison, C., Bigne, E. and Monfort, V.M. (1994) The Spanish tourism industry: Analysis of its strategies and the efficacy and achievements gained from them. In A. Seaton et al. (eds) Tourism - The State of the Art: The Strathclyde Symposium (pp. 442-52). England: J. Wiley and Sons.

Castelberg-Koulma, M. (1991) Greek women and tourism: Women's co-operatives as an alternative form of organisation, In N. Redclift and T. Sinclair (eds) Working Women: International Perspectives on Labour and Gender Ideology (pp. 197-223). London: Routledge.

Chitiris, L. (1991) Hotel Management (in Greek). Athens: Interbooks.

Coccosis, H. and Parprairis, A. (1992) Assessing the interactions between environment and tourism: Case study of the island of Mykonos. Paper presented in the IV World Congress of Regional Science International, University of Balearic Islands, Palma de Mallorca, 26-9 May.

Conway, H. (1996) Greece. Travel Weekly, 1308, 39-43.

Cooper, C. and Buhalis, D. (1992) Strategic management and marketing of small and medium sized tourism enterprises in the Greek Aegean islands. In R. Teare, D. Adams and S. Messenger (eds) Managing Projects in Hospitality Organisations (pp. 101-25). London: Cassell.

Daskalantonakis, N. (1994) Quality - The future of tourism (in Greek). TO BHMA (3 July), D.9.

Divanis, A. (1994b) Tourism policy: Left on its own luck (in Greek). XENIA (October), $4-5$.

Donatos, G. and Zairis, P. (1991) Seasonality of foreign tourism in the Greek islands of Crete. Annals of Tourism Research 18, 515-19.

Douvitsas, P. (1994) Marketing Greece through British tour operators: A future perspective. MSc Dissertation, University of Surrey, Guildford.

Drakatos, C. (1987) Seasonal concentration of tourism in Greece. Annals of Tourism Research $14,582-6$.

EC (1993a) Microeconomic Analysis of the Tourism Sector. A study by the $\mathrm{pH}$ Group for European Commission, DGXXIII (September), Report XXIII/303/94-EN. Brussels: European Commission.

EC (1993b) Growth, competitiveness, employment: The challenges and ways forward into the 21st century. Bulletin of the European Communities Supplement 6/93 (White Paper). Luxembourg.

Economist (1993) Last Chance Sisyphus: A survey of Greece. Economist (22 May), 2-22.

EIU (1986) Greece (pp. 45-60). International tourist reports, National Report, No. 3.

EIU (1990) Greece (pp. 45-62). International tourist reports, National Report, No. 4.

EIU (1993) Greece - Country Profile 1992-1993: Annual Survey of Political and Economic Background. London: Economist Intelligence Unit.

EIU (1994) Greece - Country Profile 1994-1995: Annual Survey of Political and Economic Background. London: Economist Intelligence Unit.

Epilogi (1994) Economic review - The Greek Economy 1994 (in Greek). Athens.

Euromonitor (1992) Tourism in Greece. Market Research Europe (25 May), 51-63.

Fayos-Sola, E. (1992) A Strategic Outlook for Regional Tourism Policy: The White Paper on Valencian Tourism. Tourism Management 13, 45-9.

Fotis, J. (1992) Vacational lifestyle segmentation of tourists on the island of Rhodes, Greece. MSc Dissertation, University of Surrey, Guildford.

Gilbert, D. (1984) The need for countries to differentiate their tourist product and how to do so. Seminar papers for Ministers of Tourism and Directors of National Tourist Organisations: Tourism Managing for Results, University of Surrey, Guildford.

Gilbert, D. (1990) Strategic marketing planning for national tourism. Tourist Review 45 (1), 18-27.

GNTO (1985a) Survey of attributes of foreign tourists 1984-1985 (in Greek). Greek National Statistical Services. Athens: GNTO. 
GNTO (1985b) EOT-Tourism '85: Development - Participation - Quality of Life (in Greek). Greek National Statistical Services. Athens: GNTO.

GNTO (1989a) Annual report 1988 - Forecast 89: Towards Quality. Athens: GNTO.

GNTO (1989b) The study of tourism promotion: With special reference to the measures to increase Japanese tourists to Greece. Draft final report, Japan International Cooperation Agency.

GNTO (1993) Tourism towards the 2000 (in Greek). Greek National Tourism Organisation. Athens: GNTO.

Hall, M. (1994) Tourism and Politics: Policy, Power and Place. J. Wiley and Sons.

Horwath (annual) The Greek Hotel Industry (in Greek). Annual reports. Pireus: Horwath.

Jenner, P. and Smith, C. (1993) Tourism in the Mediterranean. Research report. London: Economist Intelligence Unit.

Josephides, N. (1993) Environmental Concern - What's In It for the Tourism Industry (pp. 51-6). Proceedings of the conference: Tourism and the environment: Challenges and choices for the 1990's, 16-17 November 1992, Queen Elizabeth II Conference Centre, London. Brussels: European Union.

Josephides, N. (1994) Tourism analysis. Presentation in Philoxenia international tourism exhibition, Thessaloniki, Greece.

Josephides, N. (1995) A sorry state for beautiful Greece. Travel Weekly 1261 (5 April),11.

Kalogeropoulou, H. (1993) Greece - Prospects for the tourism industry within the context of the European Single Market of 1993. Tourism Review 48 (1), 2-4.

Kassimati, K., Thanopoulou, M. and Tsartas, P. (1994) Women's Employment in the Tourist Sector: Study of the Greek Labour Market and Identification of Future Prospects. DGV Equal Opportunities Unit, Document V/409/94-EN. European Commission: Brussels.

Komilis, P. (1987) Spatial analysis of tourism in Greece (in Greek). Athens: Centre of Planning and Economic Research.

Komilis, P. (1992) The spatial structure of tourism and physical planning practices in Greece. Paper presented in conference: Tourism and environment: Issues of policy/planning/management, 23-4 October, University of the Aegean, Dept of Environment, Lesvos.

Komilis, P. (1993) Values in the Tourism Planning and Policy Making Process (pp. 224-9). Proceedings of the conference: Values and the environment, 23-4 September. Guildford: University of Surrey.

Komilis, P. (1994) Tourism and sustainable regional development. In A. Seaton et al. (eds) Tourism - The State of the Art: The Strathclyde Symposium (pp. 65-73). England: J.Wiley and Sons.

Konsolas, N. and Zacharatos, G. (1993) Regionalization of tourism activity in Greece: Problems and policies. In H. Briassoulis and J. Van der Straaten (eds) Tourism and Environment: Regional Economic and Policy Issues (pp. 57-65). Dordrecht: Kluer Academic Publisher.

Kousis, M. (1989) Tourism and the family in a rural Cretan community. Annals of Tourism Research 16, 318-32.

Kriebardis, S. and Marmagiolis, I. (1990) Tourism Activity in Greece: Problems and Perspectives (pp. 45-54) (in Greek). Economic Report of Commercial Bank, April-June. Athens: Commercial Bank.

Ktenas, S. (1994) Hoteliers ask for $15 \%$ to $20 \%$ increases for 1995 (in Greek). TO BHMA (3 July), D.9.

Ktenas, S. (1996) Crisis in Greek tourism (in Greek). TO BHMA (7 April), D.16.

Leontidou, L. (1991) Greece: Prospects and contradictions of tourism in the 1980's. In A.M. Williams and G.J. Shaw (eds) Tourism and Economic Development: Western European Experiences (2nd edn) (pp. 94-106). London: Belhaven Press.

Logothetis, M. (1990) The Economy of Dodekanisos During 1988-1989: Developments and Perspectives (in Greek). Rhodes: Regional association of municipalities of Dodekanisos.

Logothetis, M. (1992) Touristiki Sigkiria (in Greek). Rhodes: Institute of Tourist and Hotel Research. 
Loukissas, P. (1977) The impact of tourism on regional development: A comparative analysis of the Greek islands. PhD Dissertation, Cornell University, USA.

Loukissas, P. (1982) Tourism's regional development impacts: A comparative analysis of the Greek islands. Annals of Tourism Research 9, 523-43.

Marinos, P. (1983) Small island tourism-the case of Zakynthos in Greece. Tourism Management 4, 212-15.

Moore, R. (1992) From shepherds to shopkeepers: The development of tourism in a central Greek town. PhD Dissertation, University of California at Berkeley, USA.

Moore, R. (1995) Gender and alcohol use in a Greek tourist town. Annals of Tourism Research $22,300-13$.

Mourdoukoutas, P. (1988) Seasonal employment, seasonal unemployment and unemployment compensation: The case of the tourism industry of the Greek islands. American Journal of Economics and Sociology 47, 315-29.

NSSG (1983) Tourism Statistics 1981. Athens: National Statistic Service of Greece.

NSSG (1985) Tourism Statistics 1982-1983. Athens: National Statistic Service of Greece.

NSSG (1987) Tourism Statistics 1984-1985. Athens: National Statistic Service of Greece.

NSSG (1990) Tourism Statistics 1986-1987. Athens: National Statistic Service of Greece.

NSSG (1993) Tourism Statistics 1988-1990. Athens: National Statistic Service of Greece.

OECD (1992) Greece, Tourism Policy and International Tourism in OECD Member Countries (pp. 70-8). Paris: OECD.

Ottaway, M. (1992) Turtle power. Sunday Times, Travel and Style (28 June).

Ottaway, M. (1993) Greece: The ultimate island guide - Part 1. Sunday Times (17 January), 5.7-5.9.

Panagiotopoulou, R. (1990) The problem and perspectives of the European insular regions (in Greek). Working paper, University of the Aegean, Chios.

Papadimitris, G. (1988) Short run and long run prospects of the Greek tourism industry. PhD Dissertation, University of Manchester, Manchester.

Papadopoulos, S. (1985) An economic analysis of foreign tourism in Greece: An examination of the growth and structure of foreign tourism to Greece 1960-1984 with a planning model and marketing policy recommendations. PhD Thesis, University of Bradford Management Centre, Bradford.

Papadopoulos, S. (1987) Strategic marketing techniques in international tourism. International Marketing Review (summer), 71-84.

Papadopoulos, S. (1988a) An examination of non-economic factors related to tourism in Greece. Tourism Review 43 (1), 29-30.

Papadopoulos, S. (1988b) An examination of non-economic factors related to tourism in Greece. Tourism Review 43 (2), 24-7.

Papadopoulos, S. (1989) Greek marketing strategies in the Europe tourism market. Service Industries Journal 9, 297-314.

Papadopoulos, S. and Mirza H. (1985) Foreign tourism in Greece: An economic analysis. Tourism Management 6, 125-37.

Papandropoulos, A. (1995) The crisis in tourism is evident (in Greek). Oikonomikos Tachydromos (29 June), 26-8.

Papanikos, G. (1999) The year 2004 olympic games and their influence upon the Greek tourism (in Greek). ITEP (Research Institute for Tourism): Athens.

Paulopoulos, P. (1999) The Size and Dynamics of the Tourism Sector (in Greek). Research Institute for Tourism: Athens.

Peterson, C. (1990) Greece tackles overbuilding in tourism areas. Environmental Conservation 17, 166-8.

Plevris, V. (1995) Alarm bells from the Hellenic Federation of Hotels (in Greek). XENIA 128 (May), 6-7.

Poon, A. (1987) Information technology and innovation in international tourism implications for the Caribbean tourism industry. PhD thesis, Science Policy Research Unit, University of Sussex, Brighton.

Poon, A. (1988) Flexible specialisation and small size - the case of Caribbean tourism. DRC Discussion Paper 57. SPRU, Brighton: University of Sussex. 
Poon, A. (1989) Competitive strategies for new tourism. In C. Cooper (ed.) Progress in Tourism Recreation and Hospitality Management (vol. 1) (pp. 91-102). London: Belhaven Press.

Poon, A. (1990) Flexible specialisation at small size: The case of Caribbean tourism. World Development 18, 109-23.

Poon, A. (1993) Tourism, Technology and Competitive Strategies. Oxford: CAB International.

Porter, M. (1980) Competitive Strategy: Techniques for Analysing Industries and Competitors. New York: Free Press.

Porter, M. (1985) Competitive Advantage: Creating and Sustaining Superior Performance. New York: Free Press.

Porter, M. (1990) The Competitive Advantage of Nations. New York: Free Press.

Prurier, E., Sweeney, A. and Geen, A. (1993) Tourism and the environment: The case of Zakynthos. Tourism Management 14, 137-9.

Psoinos, P. (1994a) Research on the foreign tourists' attributes in Greece (in Greek). Athens: Greek National Tourism Organisation.

Psoinos, P. (1994b) Research on the attributes of foreigners who have never visited Greece (in Greek). Athens: Greek National Tourism Organisation.

Richter-Papaconstantinou, C. (1992) Tourism development of Rhodes. Cahiers du Tourisme (Serie B) 67. Aix en Provence: Centre des Hautes Etudes Touristiques.

Romanos, A. (1998) Unification of Athens Archaeological Sites (in Greek). Athens: Unification of Athens Archaeological Sites SA.

SETE (1993) Tourism: Developments and problems (in Greek). Athens: Association of Greek Tourism Enterprises.

Sezer, H. and Harrison, A. (1994) Tourism in Greece and Turkey: An economic view for planners. In A. Seaton et al. (eds) Tourism - The State of the Art: The Strathclyde Symposium, pp.74-84. England: Wiley and Sons.

Skoulas, N. (1985) Holidays and travel in the year 2035 - Contribution of the National Tourist Organisation of Greece. SDI Schriftey Wirtschafts und Unternehmenspolitik 40, 181-99.

Skoulas, N. (1994) Quality improvement of tourism services (in Greek). Paper presented in the conference: Competitiveness of tourism enterprises - the role of quality, 1 April, Holiday Inn. Athens: Association of Greek Tourism Enterprises.

Smith, C. and Jenner, P. (1995) Greece. International Tourism Reports 3, 5-21.

Stavrou, S. (1978) Research of Tourism Social Acceptance in Kos Island (in Greek). Research and Development Division, Dept. A1. Athens: Greek National Tourism Organisation.

Stavrou, S. (1979) Research of Tourism Social Acceptance in Mykonos and Naxos Islands (in Greek). Research and Development Division, Dept. A1. Athens: Greek National Tourism Organisation.

Stavrou, S. (1980) Research on Tourism Awareness on the Islands Kalymnos and Leros (in Greek). Research and Development Division, Dept. A1. Athens: Greek National Tourism Organisation.

Stavrou, S. (1984) Tourism Development in Greece during 1969-1982 (in Greek). Research and Development Division, Dept. A1. Athens: Greek National Tourism Organisation.

Stavrou, S. (1986a) Research for the Characteristics of Foreign Tourist Demand in Greece in the Years 84/85 (in Greek). Research Division, Dept. A1. Athens: Greek National Tourism Organisation.

Stavrou, S. (1986b) Research on the Tourism Awareness on Paros, Santorini, Kythira Islands (in Greek). Research and Development Division, Dept. A1. Athens: Greek National Tourism Organisation.

Stavrou, S. (1986c) Critical Review of Tourism Activity in the Years 83/85 (in Greek). Research and Development Division, Dept. A1. Athens: Greek National Tourism Organisation.

Stavrou, S. (1988) Tourism in the Northern Aegean Islands. Presentation of GNTO for the Tourism Development of the Periphery (in Greek). Proceedings of the first conference for the development of the Northern Aegean islands, Homereum cultural centre, Chios, 11 November. Chios: Periphery of Northern Aegean islands.

Stavrou, S. (1989a) GNTO Presentation for the Tourism Development Possibilities for the Southern Aegean Islands (in Greek). Conference for the development of Southern Aegean 
islands, Syros, 30 September -2 October.

Stavrou, S. (1989b) The Contribution of the Development Law 1262/82 in the Development of the Country (in Greek). Research and Development Division, Dept. A5. Athens: Greek National Tourism Organisation.

Stereopoulos, N. (1995) It is regarded ideal, it became problematic (in Greek). Oikonomikos Tachidromos (21 December), 151-3.

Touloupas, P. (1996) Greece as a tourist destination for the British tour operators: An analysis from a marketing perspective in the particular context of the United Kingdom. MSc Dissertation, University of Surrey, Guildford.

Tourismos ke Oikonomia (1993) 20 years: 1973-1993 (in Greek). Special Issue. Athens.

Tourismos ke Oikonomia (1994) ICAP tourism enterprises: Drastic reduction of loses in 1993 (in Greek). December, 14-15.

Touristiki Agora (various issues) (Monthly tourism industry periodical in Greek). Business Press: Athens.

Truett, D. and Truett, L. (1987) The response of tourism to international economic conditions: Greece, Mexico and Spain. Journal of Developing Areas 21, 177-90.

Tsartas, P. (1989) Socioeconomic Impacts of Tourism Development in Cyclades Region with Special Reference on Ios and Serifos Islands During 1950-1980 (in Greek). Athens: National Centre for Social Research.

Tsartas, P. (1992) Socioeconomic impacts of tourism on two Greek isles. Annals of Tourism Research 19, 516-33.

Van Den Bergh, J. (1993) Tourism development and natural environment: An economic-ecological model for the Sporades islands. In H. Briassoulis and J. Van Der Straaten (eds) Tourism and Environment: Regional Economic and Policy Issues (pp. 67-83). Dordrecht: Kluer Academic Publishers.

Velissariou, E. (1991) Die Wirtschaftlichen Effekte des Tourismus Dargestell am Beispiel Kretas (The Economic Impacts of Tourism on Crete). PhD Dissertation, University of Munich. Frankfurt: Peter Lang.

Vernikos, N. (1987) The study of Mediterranean small islands: Emerging theoretical issues. Ekistics 54 (323-4), 101-9.

Wanhill, S. (1993) Government organisations. In C. Cooper, J. Fletcher, D. Gilbert and S. Wanhill (eds) Tourism: Principle and Practice (pp. 145-60). London: Pitman.

Wickens, D. (1994) Consumption of the authentic: The hedonistic tourist in Greece. In A. Seaton et al. (eds) Tourism - The State of the Art: The Strathclyde Symposium (pp. 819-25). England: J.Wiley and Sons.

Wickens, E. (2000) Rethinking tourists' experiences. In M. Robinson et al. (eds) Motivations, Behaviour and Tourist Types (pp. 455-72). Business Education Publishers: Sunderland.

Wickers, D. (1993) Greece: The ultimate island guide - Part 2. Sunday Times, 5.7-5.10.

Wilkinson, P.F. (1989) Strategies for tourism in islands microstates. Annals of Tourism Research 16, 153-77.

XENIA (various issues) (Monthly bulletin of the Greek Hotel Chamber, in Greek). Athens.

Zacharatos, G. (1984) Tourismus und Wirtschafts-Struktur. Dargestellt am Beispiel Griechenlands. Europaische Hochschulschriften, Reihex, Band 7, Frankfurt am Main.

Zacharatos, G. (1986) Tourism consumption (in Greek). Athens: Centre of Planning and Economic Research.

Zacharatos, G. (1988) The simplistic empiricism: Tourism policy and the time of crisis (1992) (in Greek). Sychrona Themata 11 (May), 21-6.

Zacharatos, G. (1989) The problems and perspectives of tourism in Greece (in Greek). In H. Katsoulis, T. Giannitsis and P. Kazakos (eds) Politics and Society, Economy and Foreign Relationships (pp. 273-89). Athens: Papazisis.

Zacharatos, G. (1993) The necessity of multimedia use in the tourism education in Greece (in Greek). Paper presented at the international conference: Overcoming isolation-telematics and regional development, University of the Aegean, Chios, 30 April - 2 May. 